\title{
Past glacier (Würmian) ice thicknesses in the Karakoram and on the Deosai Plateau in the catchment area of the Indus river
}

\author{
Matthias Kuhle ${ }^{*)}$
}

Keywords: Karakoram, glacial geomorphology, last glacial period, coalescing ice stream network, glacier thickness, Tibet

\begin{abstract}
Geomorphological and geological field and laboratory data indicate that the glacier network in the Indus river catchment area (Central Karakoram Mountains and Deosai Plateau), that is the mountain area which continues immediately $\mathrm{W}$ of the Tibetan Plateau and forms the western prolongation of the Himalaya, reached a maximum thickness of about $2400-2900 \mathrm{~m}$. They show that during the last glacial period between c. 60 and $18 \mathrm{ka}$ the Central Karakoram and its southern slope were covered by a continuous, c. $125,000 \mathrm{~km}^{2}$-large glacier network. The glaciers converged into the Indus glacier. The tongue of the Indus glacier descended to 850 $800 \mathrm{~m}$ asl. In its central part the Indus glacier network reached an altitude of more than $6000 \mathrm{~m}$ asl.
\end{abstract}

[Die würmzeitliche Gletscheroberfläche und die maximalen Eismächtigkeiten im Karakorum und auf dem Deosai Plateau im Einzugsbereich des Indus]

Kurzfassung: Es werden geomorphologische und quartärgeologische Gelände- und Labordaten und deren Auswertung zur maximalen würmzeitlichen (ca. 60-18 ka) Vergletscherung von Zentral- und Süd-Karakorum sowie auf dem Deosai Plateau vor-

\footnotetext{
*Anschrift des Verfassers: Matthias Kuhle, Geography and High Mountain Geomorphology, Geographisches Institut der Universität Göttingen, D-37077 Göttingen, Germany, E-mail: mkuhle@gwdg.de
}

gelegt. Sie zeigen, dass der Zentral-Karakorum und seine Südabdachung im Zeitraum zwischen etwa 60 und $20 \mathrm{ka}$ von einem zusammenhängenden, ca. 125 $000 \mathrm{~km}^{2}$ großen Eisstromnetz mit einer Mächtigkeit von 2400-2900 m bedeckt gewesen sind. Dieses Eisstromnetz ist zum Indus-Gletscher zusammengeflossen. Das Zungenende des Indus- Gletschers reichte bis auf 850-800 m ü. M. hinab. Die Oberfläche des Indus-Eistromnetzes lag in seinem Zentrum bei gut $6000 \mathrm{~m}$ ü. $\mathrm{M}$.

\section{Aim of the study and characteristics of the investigation area}

Before the author has visited the area of this study (Fig. 1), he investigated neighbouring topographically and climatically representative key areas from 1986 to 1996 and in 1999 . His investigations were focused on the question, if these areas were glaciated or not and if so, how extended and thick the past ice covers were, situated in the western Himalaya including Zansgar Himal and the Nanga Parbat massif, in the western Kuenlun and Tibet up to the Ladakh Range and in the northern and northwestern Karakoram (Fig. 2, hatched). In all these areas he has found indicators providing evidence of an extended valley-ice-streamnetwork and a plateau glaciation. In 1997 and 2000 the two geomorphological expeditions in the area that is shown in Figure 1, took place. They led to the Central Karakoram (Muztagh and Haramosh group) and across the Deosai Plateau, both belonging to the catchment area of the middle Indus (Fig. 2, frame of Fig. 3 and 


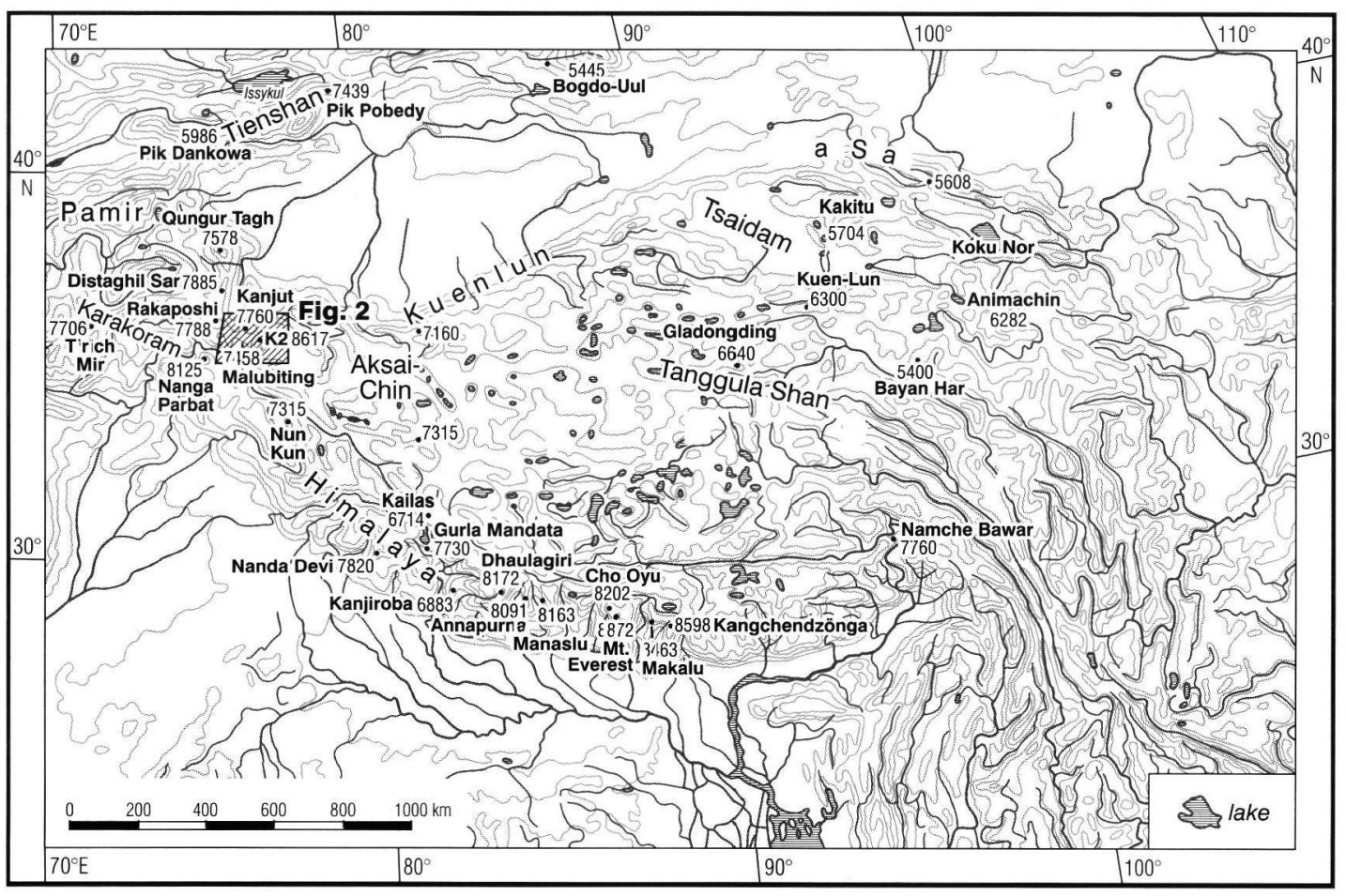

Cartography: A. Flemnitz

Draft: M. Kuhle (2002)

Fig. 1: Position of the investigation areas (hatched) in the Karakoram on the western margin of Tibet visited during the expeditions in 1997-2000.

4; Fig. 4). The aim of the fieldwork in these areas was to investigate if they - despite their current semiaridity - were also glaciated, and to find geomorphological and sedimentological indicators of a past glaciation and its extension during the last glacial period.

The current climate on the southern slope of the Karakoram is sub-tropical-semiarid. From 1951 to 1989 the annual precipitation in the Skardu Basin on the bottom of the Indus valley at $2181 \mathrm{~m}$ asl (Fig. 4, climate station 1) reached only $208 \mathrm{~mm} / \mathrm{yr}$ (MieHe et al. 2000). Here, in the centre of the study area, the mean annual temperature is $11.5^{\circ} \mathrm{C}$ (Miene ibid.). The lowest recorded temperature reached $-21.0^{\circ} \mathrm{C}$ (Miene ibid.). On the glaciers above the current glacier equilibrium line altitude (ELA = glacier snow line) about 5000-5400 m asl, precipitation increases exponentially to markedly above $1000 \mathrm{~mm} / \mathrm{y}$. This has been shown by measurements of glacier evaporation and glacier run-off in the Karakoram. The ablation of the K2 north-glacier is $1200-1300 \mathrm{~mm} / \mathrm{y}$, of the Skamri glacier 1300-1400 mm/y and of the Sarpolago glacier (Fig. 4) at least $1500 \mathrm{~mm} / \mathrm{y}$ (DING 1987:25). According to the gradient of 0.6 to $0.7^{\circ} \mathrm{C} / 100 \mathrm{~m}$ measured in 1986 between 3960 and $5330 \mathrm{~m}$ with four climate stations on the valley bottom (2 stations) and on the K2 north-glacier (2 stations), the annual mean temperature at the ELA $(5300 \mathrm{~m}$ asl) is -10.1 to $-12.3^{\circ} \mathrm{C}$ (Fig. 4, climate stations $2-5$ ). This corresponds to the glacier ice temperature of $1^{\circ} \mathrm{C}$ at an ice depth of more than $10 \mathrm{~m}$ and indicates semiarid, cold glaciers (KuHle 1988a: 414). XIE (1987), and ourselves measured $-6^{\circ} \mathrm{C}$ for ice at $8 \mathrm{~m}$ depth at the same locality (6.10.86). This is thus only an approximate confirmation of the author's calculation and points to a somewhat greater humidity. 
Today the area is still heavily glaciated. Despite its sub-tropical position at about $35^{\circ} \mathrm{N}$ the largest extra-arctic and extra-subarctic glaciers occur there. The Baltoro glacier is $60 \mathrm{~km}$ long (Fig. 2 and 4). As a joint system the Biafo-Hispar glacier extends over $74 \mathrm{~km}$ on the Hispar pass (Fig. 3, No. 67; Fig. 4). The $38 \mathrm{~km}$ long Chogolungma glacier reaches down farthest (Fig. 4). It comes to an end in the Basna valley at $2900 \mathrm{~m}$ asl (Fig. 3, between No. 59 and 60). For the Aletsch glacier in the Alps the accumulation area ratio (AAR) - which indicates the ratio of the glacier-feeding to the ablation area - is 0.66 , i.e. the feeding area is twice the size of the ablation area. In the Karakoram, however, this ratio is halfed. Here, the AARs are c. 0.4-0.3. The Baltoro glacier, for instance, with an AAR of 0.3 , maintains a stable position of the tongue end, despite this poor situation of nourishing. But it is impossible that it has come into being under these conditions. Accordingly, especially the largest valley glaciers of the investigation area seem to have received their ice masses from significantly cooler periods of the ending Late Glacial. Supporting for this stability of preservation are the large-scale, metres-thick surface moraines which are a protection against ablation over decakilometres.

\section{Methods and further informations for the understanding of the findings and interpretations}

Glaciogeomorphological observations in the research area have been mapped in detail (Fig. 2). Locations of typologically unambiguous individual phenomena, i.e. glacier indicators, have been recorded with the help of 31 signatures (Fig. 3). In this study the significance of "glacial striae" (Fig. 3), "roches moutonnées and related features of glacial polishings" like glacially streamlined hills or "glacial flank polishings and abrasions" lies in the fact that they can be interpreted as glacigenic erosional forms (Fig. 5, 7). Corresponding to the height of their position in the relief, i.e. up the valley flanks (Fig. 9) or even on mountain ridges or "transfluence passes" between two valleys (Fig. 3, 10), they provide evidence of a glacier filling up to the corresponding glacier level. This applies also to "glacially triangular-shaped slopes (truncated spurs)" (Fig. 3, 5, 7). Here, segments of valley flanks between inflowing tributary valleys are concerned, which have been polished back glacigenically (Fig. 5, 7). At the same time these are elements of the larger form "glacial trough" (Fig. $3,5,7)$. According to roughnesses above, as e.g. wall gorges and gullies and a "polish or abrasion line" (Fig. 6, 8) which separates the smooth and the rough rock face, the glacier trimline is recognizable. Corresponding observations can be made with the help of the trough cross-profile. Where its concave course comes to an end in an upward direction, the minimum altitude of the glacial trimline is reached (Fig. 5; 6a, b, d; 8b, c). "Glacial horns" (Fig. 3) belong to the same glacigenic forms of erosion as troughs. These are summits between two trough valleys which have received their significant steepness by glacigenic undercutting and back-polishing on two sides. They indicate a mountain relief filled by glacier ice very far upward and are thus evidence of past ice stream networks. In many places "rock crumblings on past flank polishings" (Fig. 5) as well as "rock avalanches" (Fig. 3) suggest past glacigenic forms, because they are gravitational mass movements on flanks which have been oversteepened by glacier polishing, i.e. "trough valley flanks". The typically Postglacial reshaping of "glacial troughs" by "fluvial undercutting of the valley flanks" (Fig 3) is a further factor which prepares "rock crumblings on past flank polishings" and "rock avalanches". The widespread occurrence of these secondary features of erosion proves the development from a glacigenic relief of a trough valley of the last glacial period to an interglacial V-shaped valley relief. 


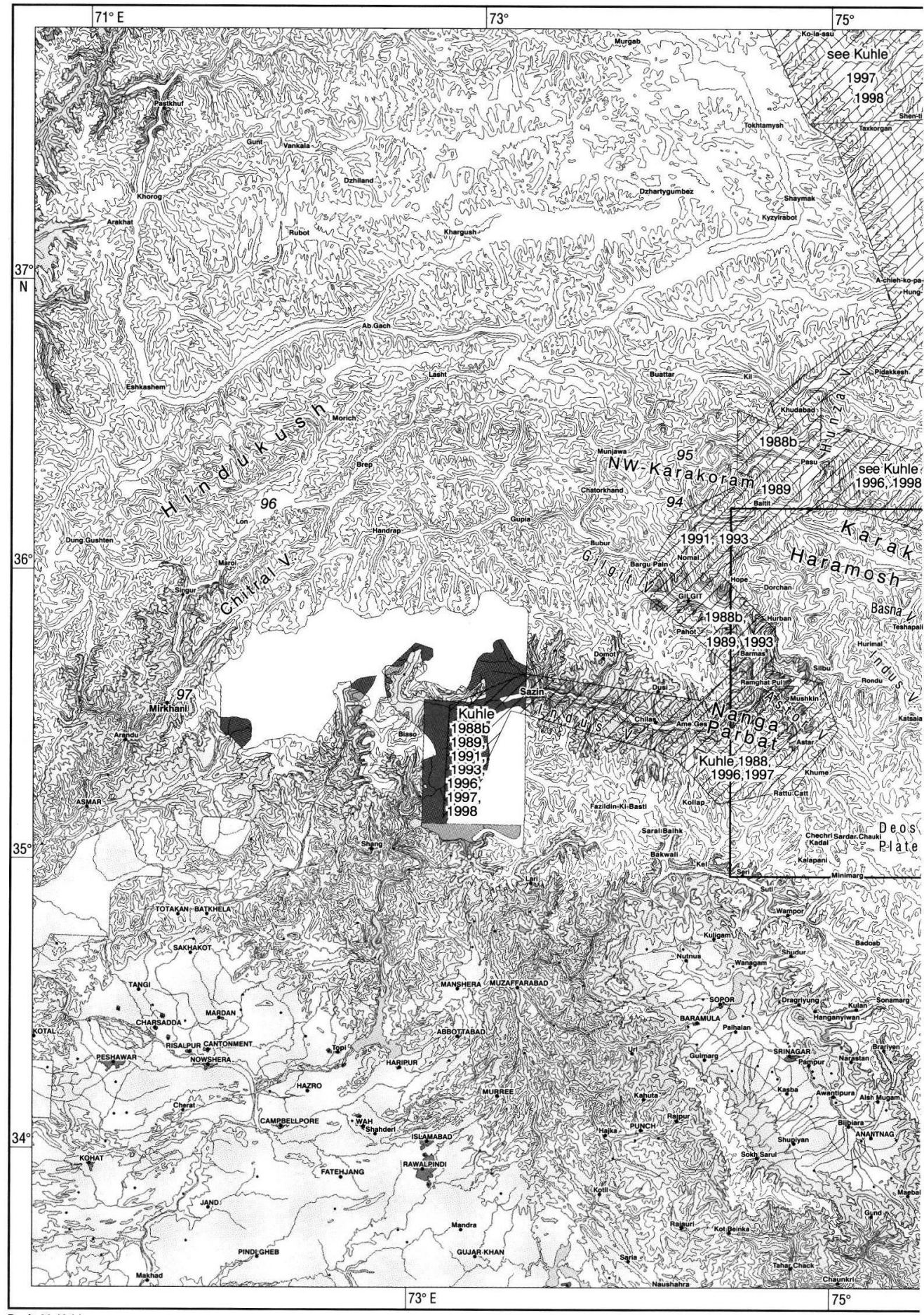

Fig. 2: Topographic map indicating the glacier network of the Karakoram, West-Himalaya and West-Tibet during the last glacial period. In this study the Würmian glacier cover is presented for the area marked by the frame. 


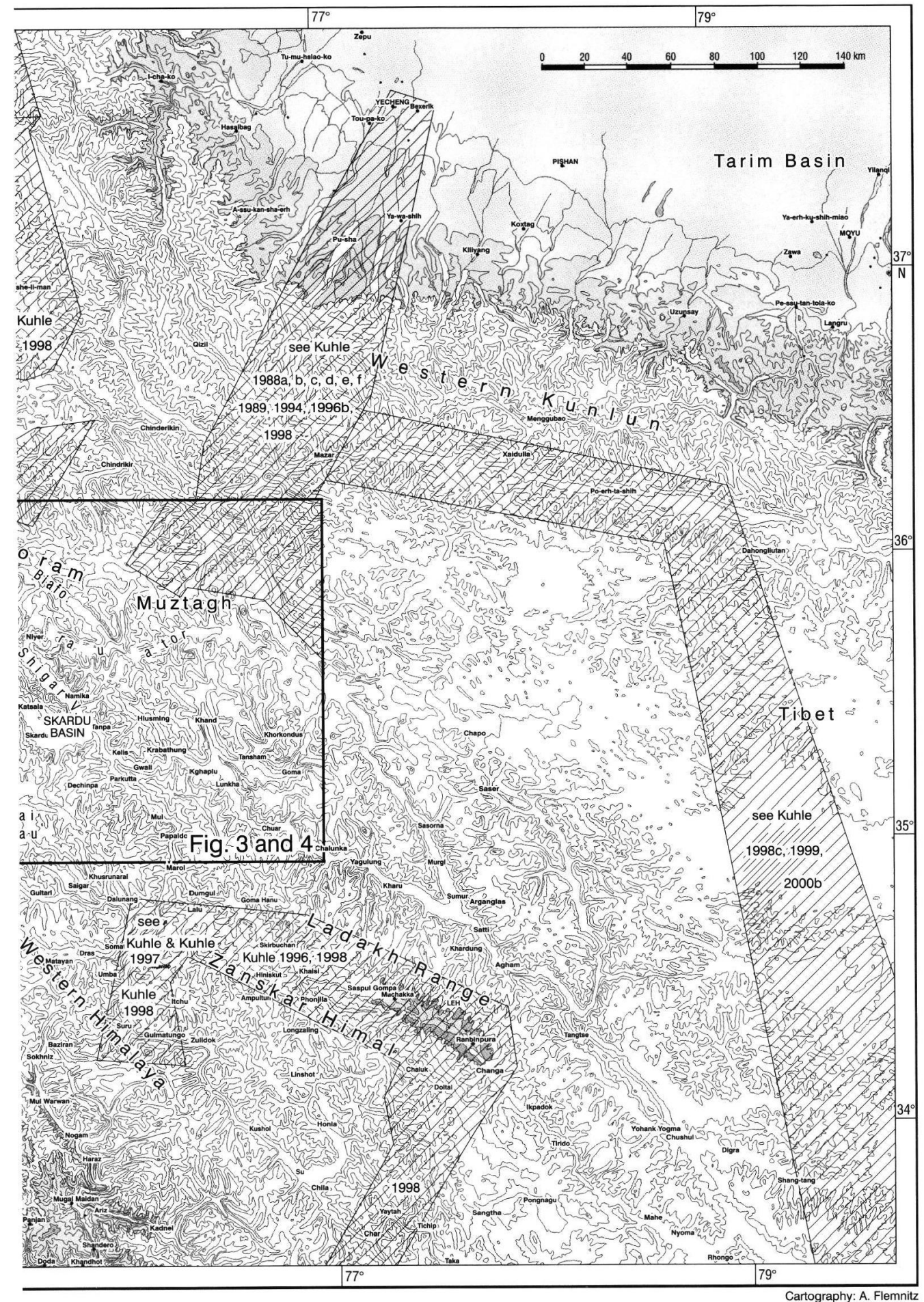




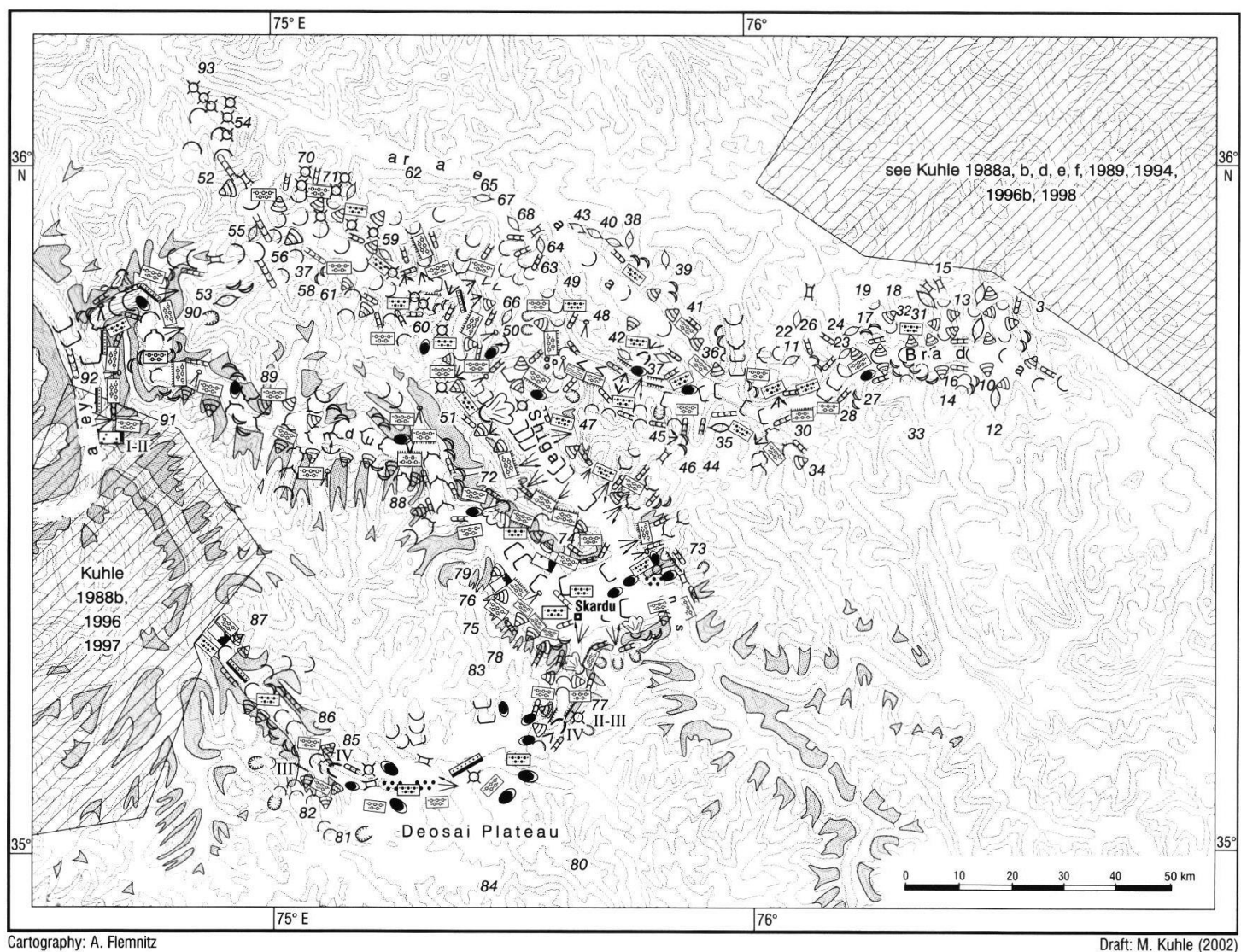

REFERENCE:

15 locality of detailed geomorphological 5 field observations

roches moutonnées and related features of glacial polishing

¿a sampling

$\because: 0$ ground moraine with erratic boulders

all.... alluvial terraces in contact with moraines

$\mathbb{M}$ alluvial fan, outwash fan

A debris flow cone

? fluvial undercutting of the valley flank

$\because$ kames and subglacial gravel deposits

ㄱ. transfluence pass

glacial flank polishing and abrasion $\theta$ glacially triangular-shaped slopes (truncated spurs)

E. cirque

( 2 terminal moraines of valley glaciers

سسس lateral moraine, middle moraine, terminal moraine (former ice margin)

$\cup$ glacial trough without and with gravel-bottom

$\checkmark$ gorge-like trough

$\because \quad$ large boulders (erratic or not erratic)

$\checkmark$ subglacial ravine cut into the floor of a glacial trough

E: glacier striae

$\checkmark \quad$ V-shaped valley

$\prec$ glacial horn
I-IV Late glacial, Neo-glacial to historical glacier stages (explanation in text)

o:o:o: pedestal moraine, pedestal ground moraine with escarpment

:o:- ground moraine with large non-erratic boulders

A rock crumblings on past flank polishings

$\AA$ earthpyramids

低 rock avalanche

$\therefore$ pot-holes

$\uparrow$ moraine slide

$\bigcirc$ area without glacier cover

$Z$ former investigation areas

Fig. 3: Map showing geological and geomorphological findings of the Central-Karakoram and Deosai Plateau between the Braldu valley in the E, the Hispar valley in the N and the lower Indus valley in the W (between K2 and Nanga Parbat). 
Owing to this, it is a secondary characteristic of the past glacial relief. "Gorge-like troughs" (Fig. 3) are modifications of "glacial troughs" at a steep incline of the valley bottom. Here, the tractive forces within the glacier are predominant so that the ground scouring predominates over the flank polishing. "Subglacial ravines cut into the floor of a glacial trough" (Fig. 3) are indicators of the course of trough valleys below the snow-line, because they have been additionally shaped by subglacial meltwater erosion. Along the deepest valley courses they have been developed by High Glacial (LGM) activities and - when the snow-line increased - by Late Glacial activities along higher valley courses. In several mountain areas - as we will see also in the Karakoram - the latter applies also to "cirques" (Fig. 3), because during the maximum of the last glacial period the snow-line ran too low there, so that cirques couldn't be formed. Instead, an ice stream network developed, composed of valley glaciers (Fig. 2, 4). In positions high above fluvial talwegs or on rock slopes without a present-day fluvial catchment area "pot-holes" (Fig. 3) can be a hard indicator of a past ice filling of the relief supra- or subglacially canalizing the water needed for their development.

Accumulative glacier indicators which may overlie the glacial-erosive features in different forms can be observed as "ground moraine with erratic boulders" (Fig. 3, 9, 10) and "ground

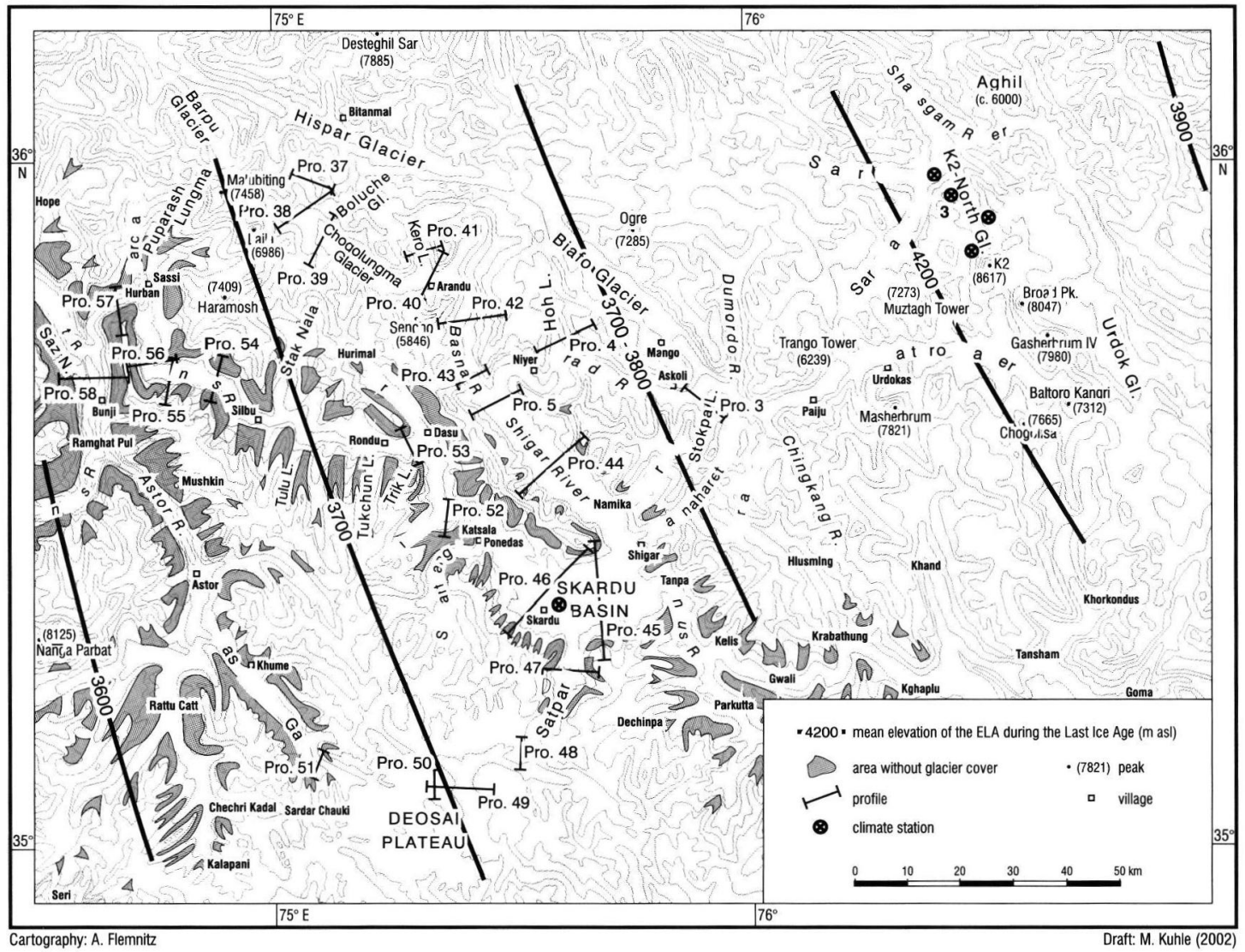

Fig. 4: The Topographic map shows localities of the glaciogeomorphological and sedimentological valley cross-profiles in the Karakoram S-slope between K2 and Nanga Parbat including the Deosai Plateau. 
moraine with large non-erratic boulders" (Fig $3,5,7)$. The higher their position above the valley bottom, the greater the former ice thickness (Fig 6, 8). The same applies to "large boulders (erratic or non-erratic)" (Fig. 3). In addition, their edged, facetted or rounded form has been taken into consideration as an indicator of the way and the distance of their transport (Fig. 7, $9,10)$. Typical of high mountain systems like the Himalaya and Karakoram and their wealth of debris is the preservation of decametres to over $100 \mathrm{~m}$-thick "pedestal moraines, pedestal ground moraines with escarpment" (Fig. 3 ). They are the result of a storey of ground moraines, one on top of the other, which have been deposited step by step during the melting process. "Earthpyramids" (Fig. 3) are characteristic residual forms of lodgement till. They are evidence of recent fluvial dissection of former glacigenic accumulations. At the same time they make understandable that the preservation of these past forms must be incomplete. This applies also to "moraine slide", "debris flow cone" and "alluvial fan, outwash fan" (Fig. 3, $5,7)$, because they concern re-deposited moraine material which originally lay higher up the valley flanks. "Kames and subglacial gravel deposits" (Fig. 3) are accumulations which are intercalated into lateral moraines. In the investigation area they have developed during the Post-High Glacial decay of ice. "Alluvial terraces in contact with moraines" are forms of glacifluvial dissection of older sanders caused by further regression of the glacier mouth. These sander faces, i.e. outwash accumulations (Fig. $6 a, b, d$ and $8 b, c)$, form the Postglacial trough valley bottoms in several mountain areas ("glacial trough with gravel bottom") (Fig. 3) so that box-shaped profiles result (Fig. 5 and 7). The Postglacial "rock avalanches" (see above) (Fig. 3) deposit their accumulations on the gravel floor of valleys as well as on moraine accumulations (Fig. 6d).

Representative samples have been taken (Fig. 3 and Tab. 2) for laboratory analyses in order to provide a detailed diagnosis and to show the actual occurrence of lodgement till in those topographical positions which suggest former glacier trimlines at high altitudes. Data of 30 moraine samples have been analysed. The sediment analyses: $\mathrm{C} / \mathrm{N}$-determination (Elementar Analyser Leco CHN 1000), lime content determination according Scheibler (DIN 19684 Teil 5, 1977), grain size analysis ("Kombinierte Siebund Pipettanalyse" KöHN 1928, DIN 19683 Blatt 2, 1973), determination of the sorting coefficient in the matrix spectrum (ENGELHARDT 1973) and morphoscopic quartz grain analysis (MAHANEY 1995) may support and complete a proof of a huge former glacigenic landscape. The morphoscopic quartz grain analysis doesn't make it immediately possible to recognize the material as "glacially crushed or freshly weathered" (Fig. 12; Tab. 2). But the petrographical analysis in the field, i.e. the content of erratic material and partly also the lime content of the debris cover, indicates that the material is glacially crushed and not freshly weathered in situ. The sorting coefficient So (EngelHardT 1973) provides further evidence for the differentiation of fluvial and morainic accumulations. If only one grain size exists in the sediment, then So is $=1$. The greater the coefficient, the more intensively mixed are the different grain sizes. This is characteristic of moraine matrix. Accordingly, the minor C-contents, the bi-trimodal grain size distribution and the lack of sorting, as well as the very high percentage of glacially crushed quartz grains provide evidence of lodgement till even up to very high positions in this steep valley relief. Thus, these analyses could be further accumulation indicators of the former ice cover and glacier thickness and - in some places even of the minimum altitudes of the trimline. "Terminal moraines of valley glaciers" and "lateral moraine, middle moraine, terminal moraine (former ice margin)" are indicators of the ablation areas. In the investigation area, where 


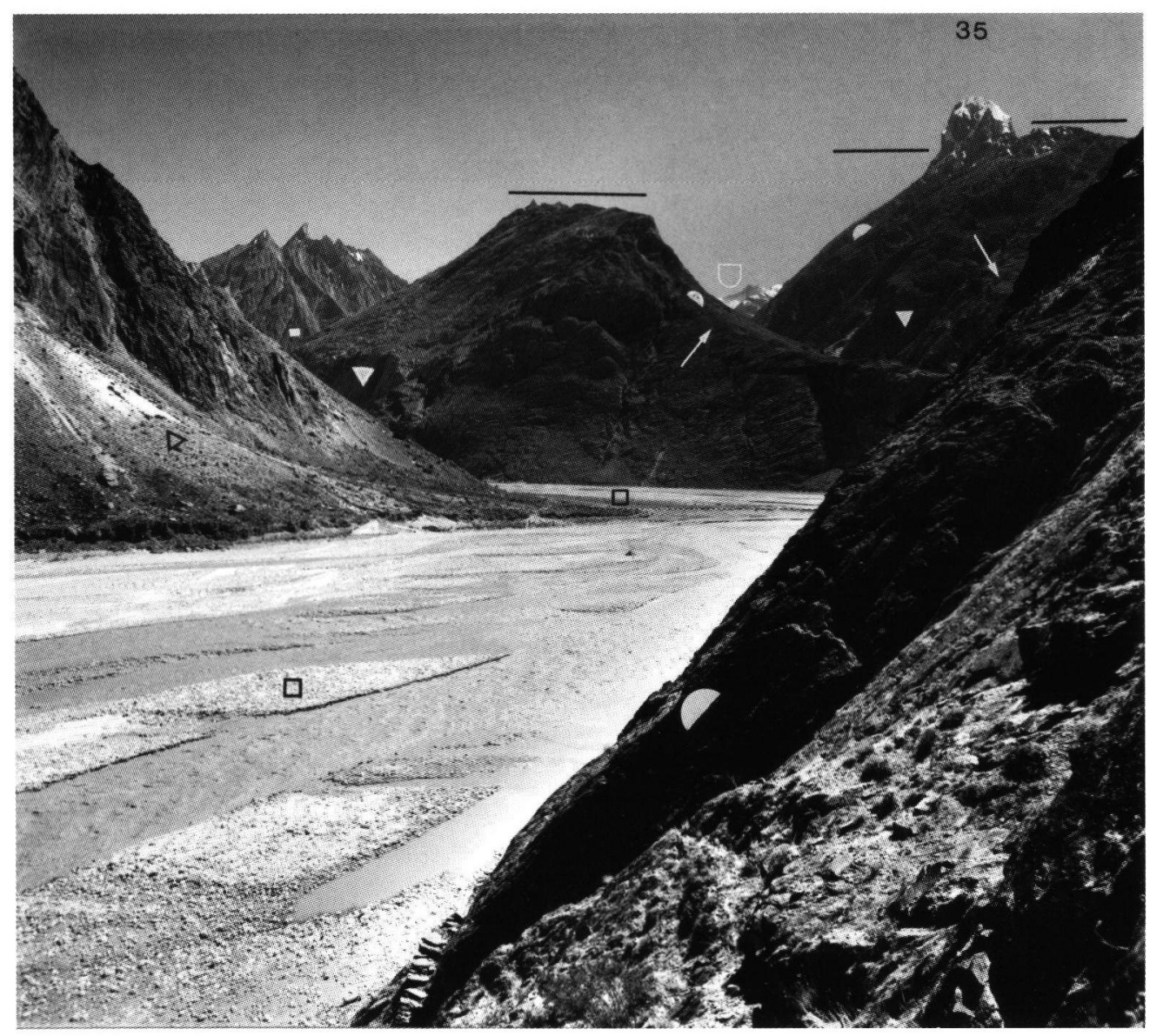

Fig. 5: View from the orographic right flank of the Dumordo valley near the locality of Jora looking from c. $160 \mathrm{~m}$ above the river ( $\square$ on the left below; Fig. 4, above Pro. 3) (3300 m asl, 35 41'50”N/ 7557’30"E) across the junction with the main valley, the Braldu Lungpa ( $\square$ on the right above), towards ESE to the 5809 m-high Bakhor Das (No. 35). The 800 m-wide, braided streamlet-network of the Panmah glacier meltwater ( $\square$ on the left below). ( ) are the rock slopes of the main and tributary valleys which have been abraded into perfectly glacigenic trough flanks (Fig. 6a). ( $\uparrow \downarrow$ and $\square$ ) show the lodgement till overlaying the valley flanks which occur up to at least $800 \mathrm{~m}$ above the gravel floor ( $\square$ ). Photo M. Kuhle, 18.8.1997.

the joint glacier terminals of the ice stream network had ended during the maximum glaciation of the last glacial period (cf. Fig. 2), there is further evidence of Late Glacial glacier margins far below the highest trimlines (Fig. 3, 7) which had already decreased. Therefore they are marked by the numbers I-IV as being of late- to neoglacial age (Fig. 3, 7). This is not the place to discuss the late- and neoglacial periods in detail. However, the existence of these younger indica- tors is important, because they indicate seven late- to neoglacial and at least four historical glacier positions. This number is approximately corresponding to that of glacier positions of the post-last-glacial period diagnosed worldwide and, owing to this, may be an important indication for dating.

The catalogue of signatures applied has been developed for the map 1:1 million (OpERATIONAL Navigation Chart G-7 1974). The locations 

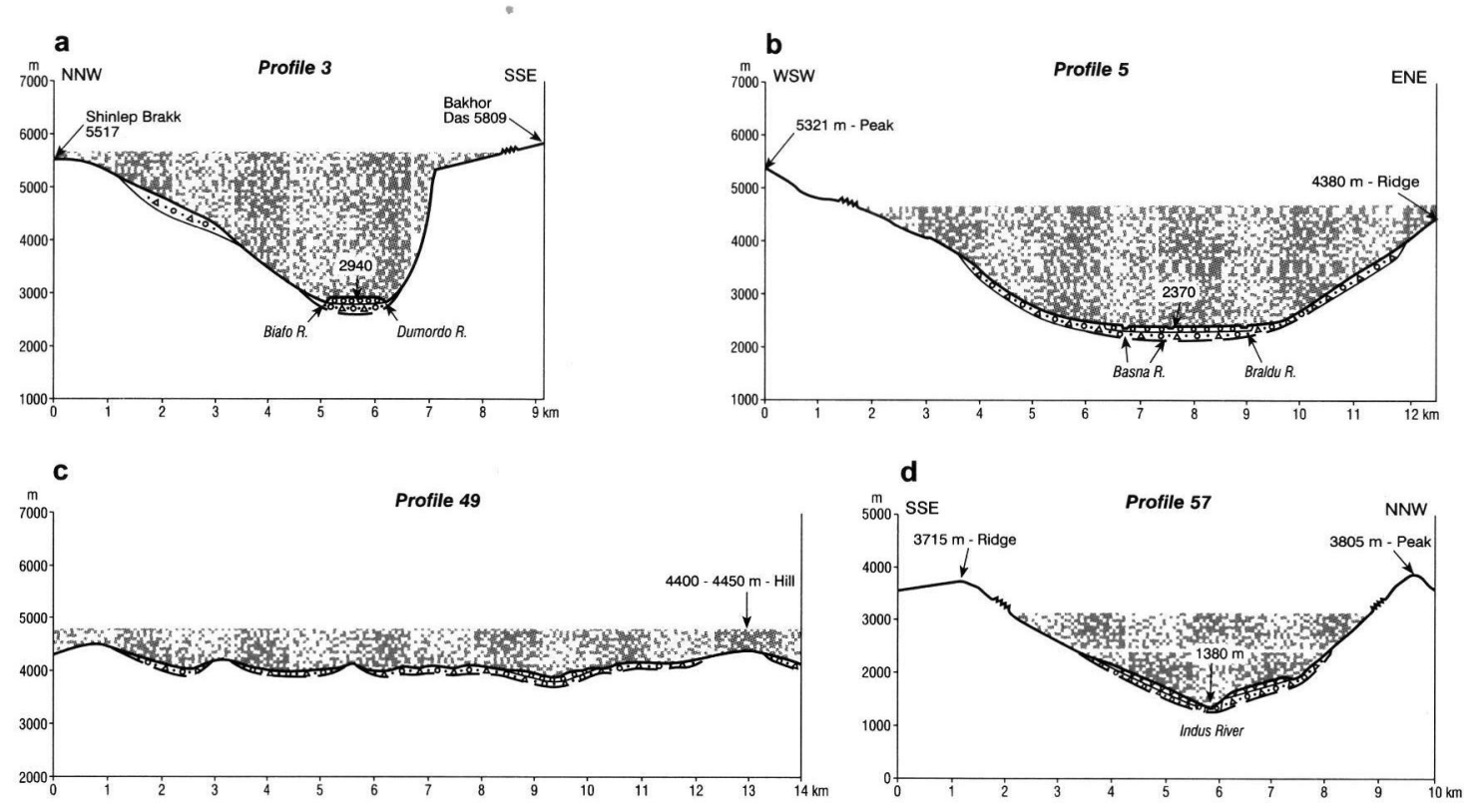

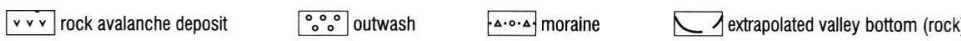

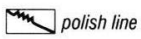

7.T. past glacier ice filling Draft: M. Kuhle

Fig. 6:

a: Cross-profile 3 (not exaggerated) of the upper Braldu valley (Biaho Lungpa) from the Shinlep Brakk (Fig. 3, No. 37) in the NNW up to the Bakhor Das (No. 35) in the SSE (see Fig. 5 and 7) with its minimum glacier ice filling reconstructed for the last glacial period. Locality: Fig. 4, Pro. 3.

b: Cross-profile 5 (not exaggerated) of the upper Shigar valley from the $5321 \mathrm{~m}$-peak (NNW of the Munbluk) in the WSW (Fig. 3, No. 51) as far as the 4380 m-ridge (NNW of the Busper) in the ENE (No. 47) with its minimum glacier ice filling reconstructed for the last glacial period (see Fig. 12; Tab. 2, Nos. 13 u. 14). Locality: Fig. 4, Pro. 5.

c: One (cross-profile 49) of three exemplary profiles (see Fig. 4) (not exaggerated) in the area of the Deosai Plateau (Fig. 3, on the right below No. 85 and on the right above No. 81, both at the same distance). The gravel cover and the lodgement till are represented as thicker than they are so as to leave the signature legible. The hilly to highland-like surface with a difference in height of $600 \mathrm{~m}$ on this WE-profile shows the area depicted in Fig. 10 (Fig. 11d; Fig. 12; Tab. 2, No. 17). The glacier surface of the last glacial period has been reconstructed according to the suggestion that it must have been situated above the hills with or without a lodgement till cover, which has been abraded by glacigenic ground scouring. This is hypothetical as the exact thickness of the ice is no longer verifiable. Due to the fact that the ELA ran c. $400 \mathrm{~m}$ below the height of the plateau (Fig. 4, Pro. 49), the ice thickness of 200-900 $\mathrm{m}$ at a compact outline of the high plain of 24 to $28 \mathrm{~km}$ on average is realistic. Locality: Fig. 4, Pro. 49.

d: Cross-profile 57 (not exaggerated) of the Indus gorge above the inflow of the Gilgit river, facing SSE (orographic left flank) to NNW (right flank) looking down-valley (Fig. 3, on the left of No. 90). The indicated glacier-filling of the relatively wide trough during the last glacial period is evidenced by lodgement tills as far as a height of c. $2400 \mathrm{~m}$ asl (orographic right). The lodgement till layers are covered with deposits of rock avalanches on both slopes; on the valley bottom, near the talweg, they have been replaced by gravel deposits. Gravel layers of washed-out lodgement till like these might be syngenetical and could have already been created beneath the glacier of the last high- to Late Glacial period. The ice-filling up to at least $3100 \mathrm{~m}$ asl is suggested by glacigenic abrasion roundings in the bedrock occurring on the upper c. $750 \mathrm{~m}$. The trough form which, compared with the up-valley cross-profiles is wide, can be explained by the decreasing incline of the valley bottom (this applies also to Profile 58: Fig. 8b; Fig. 3, on the left of No. 90). Locality: Fig. 4, Pro. 57. 
of the sediment samples, from which only a selection could be taken in consideration in this paper, are marked in Figure 3. All 92 type localities supporting the results of this study are numbered. They concern areas where the arrangement of indicators provides unambiguous evidence of a glacier cover. Within the scope of this paper it is impossible to provide a detailed description of the indicators in the particular topographical coutext of these 92 type localities. Owing to this, only the most significant glaciogeomorphological phenomena are shown, which are especially strong indicators due to their position in the valley relief. In accordance with the scale of Figure 3 they are strongly generalized. References to them are given in the text, the figures and tables. In addition to this large-scale map and the recording of type localities - which don't only occur on the valley floors but partly also on remote slopes and mountain flanks - 25 geomorphologic profiles, mainly valley cross-sections, distributed over the entire investigation area, have been recorded (Fig. 4). The seven profiles selected to provide evidence of the large-scale Würmian glaciation (Fig. 6, 8) are shown in Figure 4. Combined with the twodimensional, vertical representations in Figure 3 and 4, they give an impression of the threedimensional arrangement of the indicators leading to the reconstructed glaciated area on the one hand and the local ice thickness on the other. The aim of this is a spatial proof-system based on the arrangement of the positions, so that the profiles complete the glaciogeomorphological map especially with regard to the indication of past glacier thicknesses. Apart from that, the ice thickness provides local references as to the horizontal extension of the glacier cover. All indicators marked in the maps and profiles have been documented on the spot by photos in a medium-sized format. In this study four of these photos are shown as exemplary proofs.

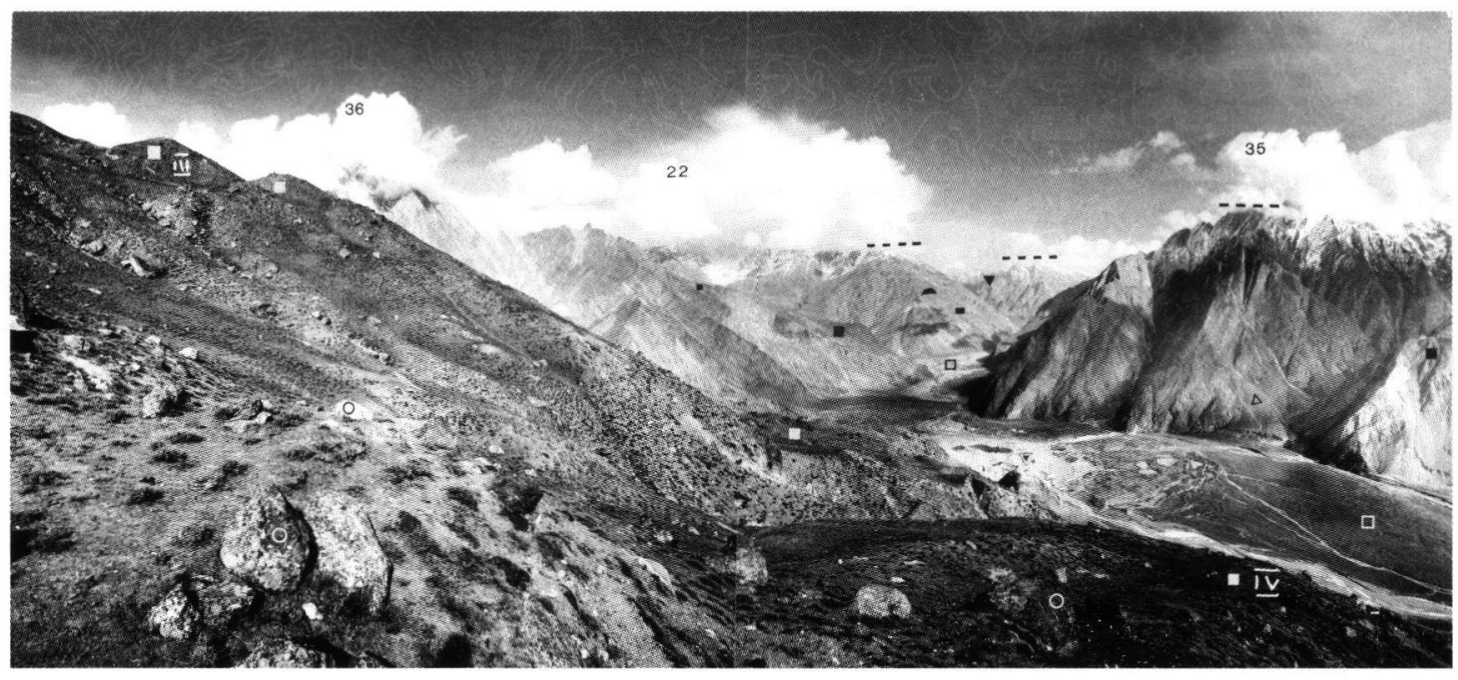

Fig. 7: At $4150 \mathrm{~m}$ asl, on the orographic right flank of the Braldu valley (3541'10”N/7552'55"E; Fig. 3, below No. 37; Fig. 4, Pro. 3), ca. $1200 \mathrm{~m}$ above its valley bottom ( $\square$ white), a decametres-thick cover of lodgement till has been preserved (Fig. 6a, below the Shinlep Brakk) overlain by a series of Late Glacial lateral moraine ramparts ( black; III and IV). Sedimentary bedrocks (phyllites) outcrop in the underground. (O) marks coarse, far-travelled erratic granite boulders up to several metres in length (Fig. 3, below and half-right below No. 37) contained in the moraines. (No. 36) is the $6294 \mathrm{~m}$-high Bullah in the NE, (No. 22) is the Choricho massif (6756 m) with its W glacier situated in the ENE and (No. 35) is the Bakhor Das (5809 m) in the SE. Photo M. Kuhle, 27.9.1997. 


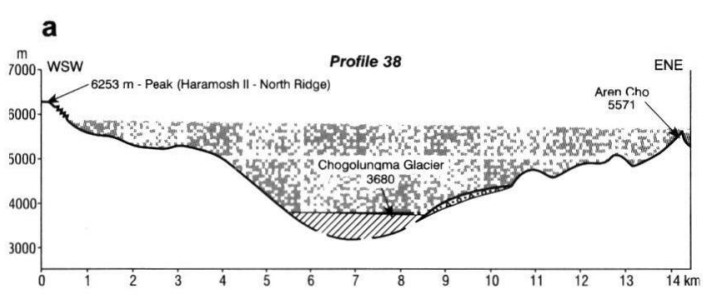

\section{b}
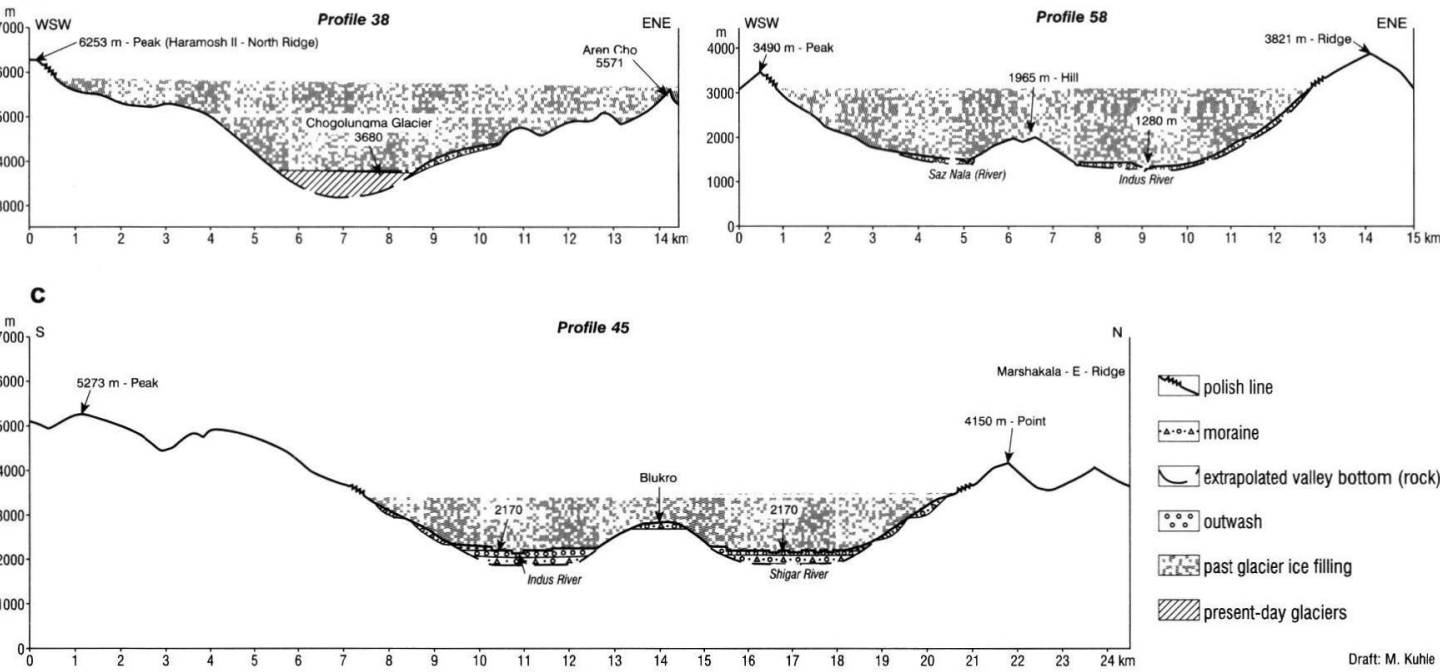

polish line

-A.०.A.moraine

$\subset$ extrapolated valley bottom (rock) $\because$ outwash

Fit. Q7Is present-day glaciers

Dratt: M. Kuhle

Fig. 8:

a: Cross-profile 38 (not exaggerated) of the upper Basna valley with the middle Chogolungma glacier from the 6253 m-peak (Fig. 3, No. 56) in the WSW on the N-ridge of the Haramosh II towards ENE as far as the Aren Cho (No. 71) on the orographic left valley side with the minimum glacier ice filling of this main valley reconstructed for the last glacial period (Fig. 12; Tab. 2, Nos. 3-8). Locality: Fig. 4, Pro. 38.

b: Cross-profile 58 (not exaggerated) of the Indus valley, $5.5 \mathrm{~km}$ down from the inflow of the Gilgit river, in the junction area of the Saz Nala (river), facing WSW (orographic right flank) to ENE (left flank) looking up-valley (Fig. 3, half-left above No. 91). The indicated last glacial period glacier-filling of the c. $13 \mathrm{~km}$-wide trough was about $1800 \mathrm{~m}$-thick and can be evidenced by a lodgement till cover up to an altitude of c. 3000 $\mathrm{m}$ asl (on the orographic left). This glacier ice-filling is also confirmed by glacigenic abrasion roundings in the bedrock which are sporadically exposed. The valley bottom is made up of terraced gravel deposits up to 2.5 $\mathrm{km}$ in width; part of these gravel layers might be syngenetic with the lodgement tills and so has already been developed beneath the last glacial period to Late Glacial (see Tab.1: Würm = last High Glacial maximum = stadium 0 to Late Glacial stadium I or II) glacier and fluvially reworked after the deglaciation. Locality: Fig. 4, Pro. 58.

c: C. $21 \mathrm{~km}$-wide cross-profile 45 (not exaggerated) of the middle Indus valley, here of the over $36 \mathrm{~km}$ long Skardu Basin between the 5273 m-peak (a NW-satellite of the $5321 \mathrm{~m}$-peak, Fig. 3, No. 77) and the Marshakala-E-ridge (on the right of No. 74), $12.3 \mathrm{~km}$ down-valley of the upper, i.e. eastern margin of the basin. The section is situated in the confluence area of the Shigar- and Indus river between the Deosai plateau in the $S$ on the orographic left and the Haramosh Range in the $\mathrm{N}$ on the orographic right valley side (Fig. 2). In the lower 1500 altitude-metres of this profile, situated $S$ and $N$ of the lodgement till-covered Blukro, the glacier ice-filling reconstructed for the last glacial period has left behind two classic trough-cross-profiles, the bedrock of which is also mantled with lodgement till in some places (Fig. 12; Tab. 2, No. 15). Locality: Fig. 4, Pro. 45. 
3 Glaciogeomorphologically reconstructed trimlines and glacier thickness of the past glacier network

The geomorphological data obtained in the field establish the sequence of the past mountain glaciation. Due to the high aridity of the investigation area which rules out $14 \mathrm{C}$-datings, and the extreme steepness of the slopes as well as the relief energy, which result in a continuous rearrangement of the unconsolidated material and, owing to this, render a reliable dating of the surface impossible, absolute age data couldn't be provided. However, thanks to favourable conditions in the $\mathrm{N}$-, E- and S-adjacent research areas (see Fig. 2 and 3) several reliable age datings have been obtained (Tab.1). They allow to fit the glaciation history of High Asia, acquired by indicators of the position of ice margins as e.g. end moraines, into an absolute chronological sequence (KuHLe 1994: 142/143 Tab.2; 1998). The chronologically analogue presentation of the glaciation history according to Table 1 carried out in the following is meaningful because of the spatial proximity to the absolute age datings introduced there.

In addition to the reconstruction of the maximum extent of the glacier cover of the last glacial period (= Würmian $=$ stadium 0 , cf. Tab. 1 ), field investigations and laboratory analyses were

Tab. 1: Glacier stadia of the mountains in High Asia, i.e. in and surrounding Tibet (Himalaya, Karakoram, E-Zagros and Hindukush, E-Pamir, Tien Shan with Kirgisen Shan and Bogdo Uul, Quilian Shan, Kuenlun with Animachin, Nganclong Kangri, Tanggula Shan, Bayan Har, Gangdise Shan, Nyainquentanglha, Namche Bawar, Minya Gonka), from the pre-Last High Glacial (pre-LGM) to the present-day glacier margins and the pertinent sanders (glaciofluvial gravel fields and gravel field terraces) with their approximate age (after KuHLe 1988a,b,c, 1989, 1991, 1994, 1997, 1998).

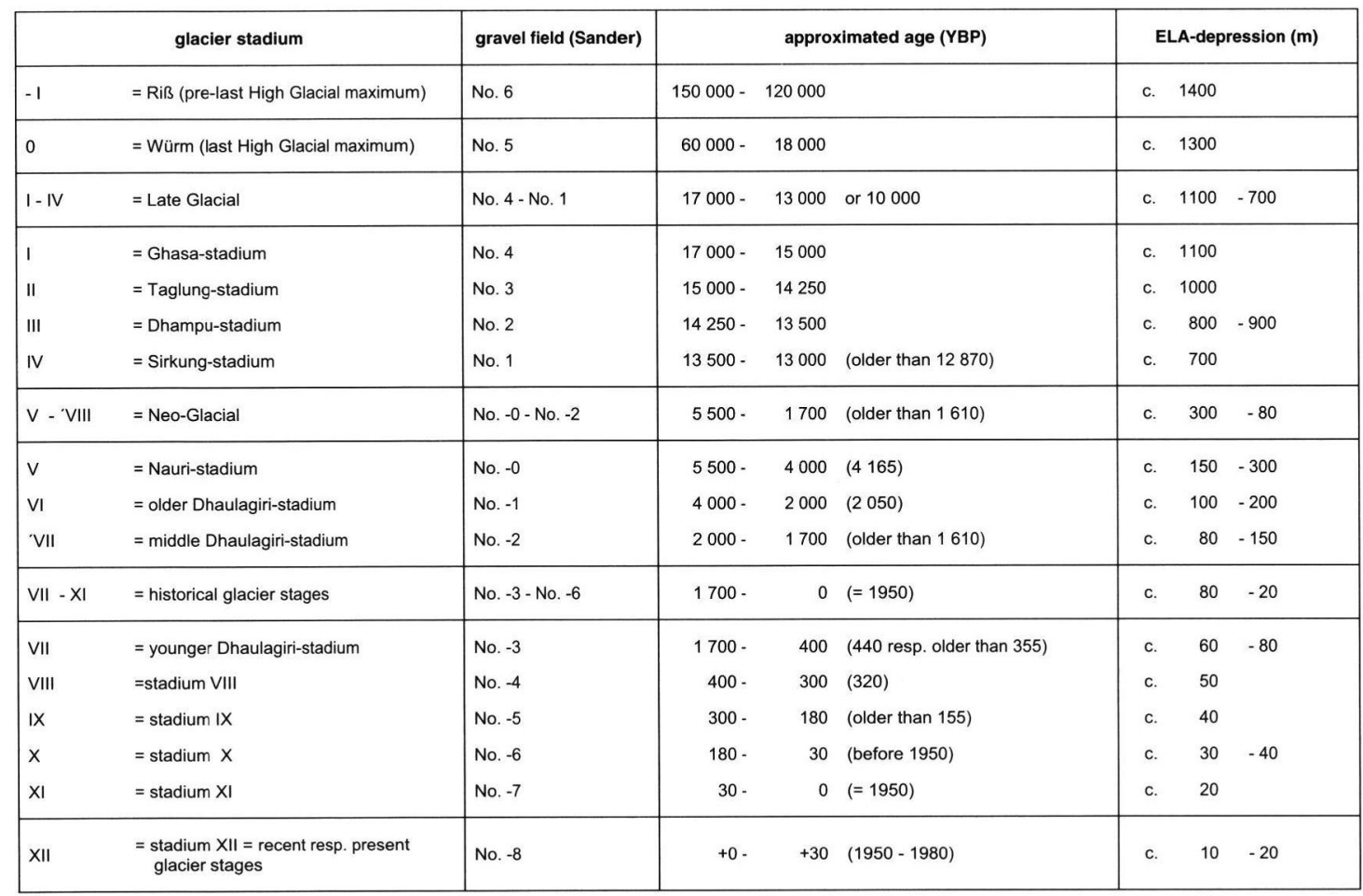


focused on the determination of trimlines and glacier thicknesses.

A continuous past glacier network (Fig. 2), as well as the extent of the Karakoram ice cover, was reconstructed (Fig. 3-5, 7, 9, 10). Some representative local trimlines are recognizable in the cross-sections of Figure 6 and 8.

With regard to the arrangement of their positions the erosive and accumulative indicators of the past glacier activities and their partly postglacial reshaping by rock crumblings, rock avalanches, debris flow cones and alluvial fans are compiled in a geomorphological map (Fig. 3 ) and proved by paradigmatic photos at key localities (Fig. 5, 7, 9, 10).

In a central section of the investigation area (Fig. 3, No. 35) Figure 5 indicates a maximum ice thickness of the past ice stream network of $2700 \mathrm{~m}$ (Fig. 6a). This was demonstrated by covers of lodgement till on the rock slopes which occur up to $800 \mathrm{~m}$ above the gravel floor and further above by flank abrasions (Fig. 5) up to a past trimline at 5700 asl. (Fig. 5). The Bakhor Lungma, a classic trough valley, leads down on the left of No. 35. It becomes apparent that its flanks have been glacigenically abraded by the past glacier ice nearly up to the top of Bakhor Das (No. 35). The rock flank in the foreground (Fig. 5) has also been polished by the glacier. The very resistant bedrock quartzite has only been slightly splintered and roughened by Postglacial weathering for c. 13,000 years. For the last time the valley was filled with glacier ice during the last Late Glacial stadium (Sirkungstadium (IV) = older than 12.870 YBP; cf. Tab. 1). Merely the fine polish is lacking, whilst the abrasive rounding has been preserved. The corresponding valley flank, however, has already been weathered and broken away more heavily (Fig. 5 left margin). The crumblings have built up an active debris cone which is undercut by the glacier gravel floor of the current Panmah glacier. Break-out scars of postglacial rock crumblings occur on the oversteepened trough valley flanks (Fig. 3, with the signatures at No. $35)$.

In place of numerous topographically similar localities in the investigation area (cf. Fig 3 No. 37) shows the High Glacial filling of the ice stream network of the deeply incised Karakoram relief up to a trimline at $5700-5900 \mathrm{~m}$ asl (Fig. 7) and also the Late Glacial ground (Fig. 7) and lateral moraines with erratic granite boulders (Fig. 7) occurring the valley flanks. Accordingly, the lateral moraines belong to the Late Glacial stadium, Dhampu (III) and Sirkung-stadium (IV) (cf. Tab. 1). The later lateral moraine which belongs to the last (youngest) Late Glacial glacier position (older than 12.870 YBP; Tab. 1) underwent an ELA-depression of c. $700 \mathrm{~m}$ against modern data. These two lateral moraines (Fig. 3 , below No. 37) are the lowest moraine ledges above the present-day valley bottom (Fig. 7). In adjacent valley cross-sections lodgement till occurs at the same level (Fig. 7) and also at an 800 m-higher level up-valley (Fig. 7 [ ; cf. Fig. 5). In places debris cones can be found, made up of lodgement till which has been replaced in a down-slope direction (Fig. 7). The glacigenic flank abrasions of the maximum Würmian glacier filling of the Braldu valley (Fig. 7) show the form of truncated spurs and glacially triangularshaped slopes (cf. Fig. 3, between below No. 36 and 23). Their upper polish line provides evidence of the last glacial period glacier trimline (Fig. 7; cf. Fig. 6a). In many places postglacial rock crumblings and break-out scars of rock avalanches are recognizable (Fig. 7). They have come down the over-steepened trough flanks during the Postglacial period, i.e. after deglaciation. The tongue of the current Biafo glacier is covered by surface moraine (Fig. 7). It comes to an end on the present-day gravel floor of the Braldu valley (Fig. 7) at $2960 \mathrm{~m}$ asl (Fig. 4, above Pro. 3).

In many places the transition from a basal mantling of ground moraine up the slope and glacigenic flank abrasion up to a polish line, i.e. 


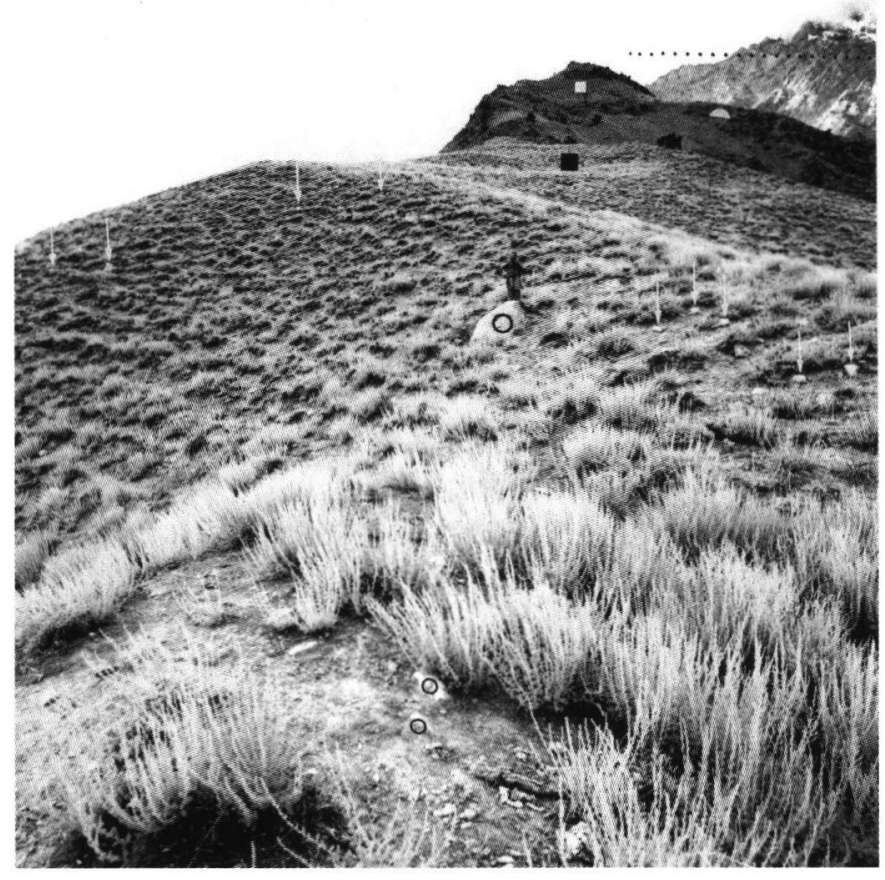

Fig. 9: At $3470 \mathrm{~m}$ asl in the orographic left flank of the Chogolungma glaciervalley $\left(35^{\circ} 53^{\prime} 10^{\prime \prime} \mathrm{N} / 75^{\circ} 13^{\prime} 17^{\prime \prime} \mathrm{E}\right.$; Fig. 3, below No. 59, Fig. 4, on the right of Pro. 39), from $200 \mathrm{~m}$ above the current glacier surface, looking up-slope in a $\mathrm{N}$-direction. The following 100 altitudemetres consist of Late Glacial lodgement till and lateral moraine ( $\mathbf{\square}$ black) of the Sirkung-stadium (IV) (Tab. 1). Here, erratic boulders of gneiss and quartzite can be found ( $O$ and $\downarrow \downarrow$ ). Photo $M$. Kuhle, 14.7.2000.

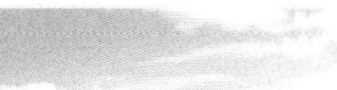

84

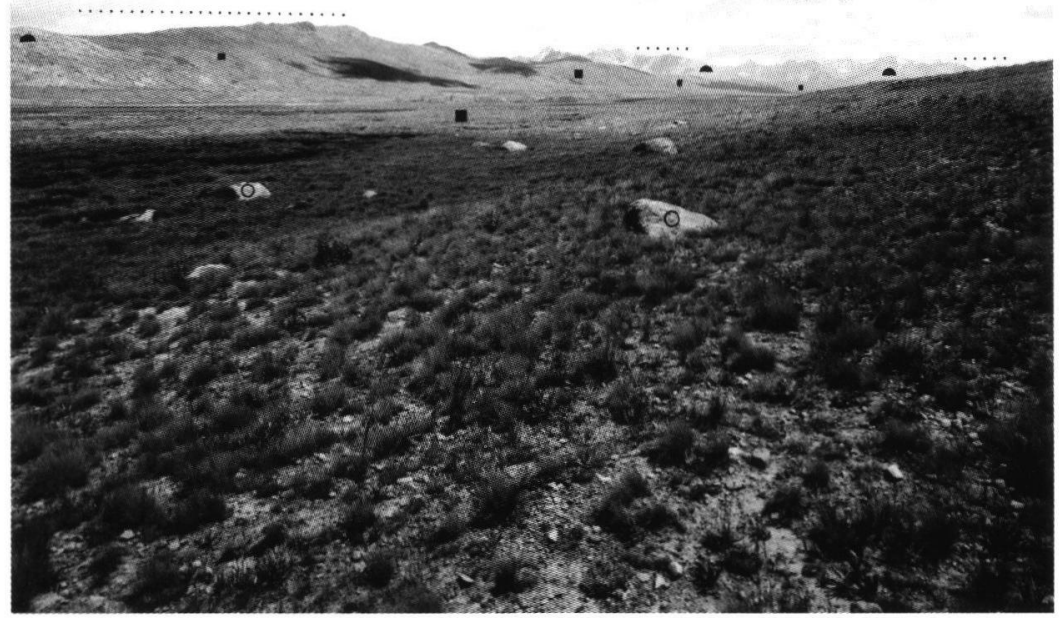

Fig. 10: At $3930 \mathrm{~m}$ asl, from the centre of the Deosai plateau $\left(35^{\circ} 00^{\prime} 32^{\prime \prime N} / 75^{\circ} 24^{\prime} \mathrm{E}\right.$; Fig. 3, between No. 85 and 84; Fig. 4, Pro. 49) looking to SSE; No. 84 is the 5193 m-massif. The large névé patches and the small avalanche-fed glaciers on the N-exposed wall feet (below No. 84) prove a current ELA about 4700 to 4800 $\mathrm{m}$ asl. Visible are typical remnants of an ice cap: wide-spread ground moraines $(\boldsymbol{\square})$ with in part large erratic boulders ( $\mathrm{O}$ ) far away from each other, roches moutonnées and glacially streamlined hills ( $\mathbf{C}$ ) providing evidence of a minimum altitude of the trimline ( $\cdots)$ at $4800-4900 \mathrm{~m}$ asl. Photo M. Kuhle, 3.8.2000. 
glacier trimline, can be observed. With regard to a more western section of the investigation area (Fig. 3, No. 5), it is introduced in Figure 9. At this locality (Fig. 9) the highest glacier trimline about $5600 \mathrm{~m}$ asl (cf. Fig. 8a) is verifiable according to a classic upper limit of glacier abrasion (Fig. 3, below No. 59). Probably it belongs to the last glacial period. This transition is characteristic because the highest trimline, which has been preserved by flank polishing (Fig. 9), has developed far above the corresponding snow-line and therefore must have been formed by glacigenic abrasion without a ground moraine accumulation worth mentioning - which should have been preserved up to these days. The lower 430 altitude-metres (Fig. 9) consist of Late Glacial lodgement till and lateral moraine (Fig. 9) of the Sirkung-stadium (IV) (Tab. 1). This moraine cover contains erratic boulders of gneiss and quartzite (Fig. 9). They are fistsized up to the size of $1.5 \mathrm{~m}$ and even $2.2 \mathrm{~m}$ at maximum (longitudinal axis) (Fig. 9), facetted and also relatively well-rounded, embedded in a pelitic matrix with relatively high content of clay compered with steep mountain areas, a bimodal grain size curve and a relatively high sorting coefficient of 3,89 (Fig. 11a) and 100\% glacially crushed quartz grains (Tab. 2, No.1; Fig. 12) (as a corresponding orographic right example for the condition of lodgement till of the Sirkung-stadium (IV) in the Basna Valley see also Fig. $11 \mathrm{~b}$, where the content of clay even reaches $13 \%$ and the sorting coefficient 5,63). Metamorphic sedimentary bedrocks outcrop in the underlying bed. They also form the rocks which have been abraded by the past glacier ice (Fig. 9) above the noticeably over 10 m-thick lodgement till cover (Fig. 9). As far as an altitude of $3700 \mathrm{~m}$ asl a somewhat older, late Late Glacial lodgement till (but still Sirkungstadium (IV); Tab. 1) (Fig. 9) lies on these rocks at a thickness of 1 to $3 \mathrm{~m}$.

An example of the different type of relief and its former completely glacial cover is the Deosai
Plateau (Fig. 3, between No. 83 and 84). From the foreground up to the 5193 m-massif (Fig. 10, No.84) the photograph shows a classic former glacial landscape with lodgement tills (Fig. 10, Fig. 6c) with $15 \%$ clay and a high sorting coefficient of 4,15 (Fig. 11d) and 100\% glacially crushed quartz grains (Tab. 2, No. 17; Fig. 12) on which a scatter of polymict, up to over $2 \mathrm{~m}$-long, round-edged, far-travelled boulders (Fig. $10 \bigcirc$ ) can be seen, pierced by abraded glacial erosion forms (Fig. 10 - ) as e.g. roches moutonnées (Fig. 10; Fig. 6c: 4400 - $4450 \mathrm{~m}$-hill). Two glacigenically triangleshaped slopes of typically truncated spurs are visible, too (Fig. 10). The boulders consist of metamorphic sedimentary rocks (phyllites). The ice level of the last glacial period (Fig. 10) ran between an altitude of 4800 (Fig. 6c) and $4900 \mathrm{~m}$ asl. The past Deosai ice-cap had several outlet glaciers (Fig. 2; Fig. 3, below No. 85 and left of No. 77). During the Würmian glaciation the Satpare Lungma outlet-glacier flowed into the Skardu basin (Fig. 3, above No. 77; Fig. 8c). During the youngest Late Glacial stadium, the Sirkung-stadium (IV) (cf. Tab.1), this outlet glacier still reached into the middle valley chamber of the Satpare Lungma as far down as $3230 \mathrm{~m}$ asl (Fig. 3, on the left below No. 77). The sedimentological characteristics of this end moraine are shown by the analysis of the grain sizes (Fig. 11c) and the morphoscopical analysis of the quartz grains (Tab. 2, No. 16 and Fig. 12). The curve of the grain sizes is trimodal and the content of $10 \%$ clay very high considering that it is a mountain valley. This points to moraine. The So of 5.62 is also typical of moraine; 98.57 $\%$ of the quartz grains are glacially crushed.

Summing up it has to be stressed that in the connection of the exemplarily geomorphological and sedimentological arrangement of the positions introduced here by typical valley sections and high plateau landscapes in the investigation area (Fig. 5, 7, 9 and 10), 99.49\% of all the quartz grains analysed from altogether 
Tab. 2: Morphometric quartz grain analyses of 29 representative samples of the Haramosh Muztagh (Chogolungma-Basna valley), Shigar valley, Skardu basin, Deosai Plateau, Malubiting-Spantik group (Barpu glacier, Rash lake), Batura-Campire Dior group (Bar valley). Fig. 12 shows the proportion of glacially crushed / freshly weathered and fluvial / aeolian grains contained in these 29 samples (cf. Figure 11).

\begin{tabular}{|c|c|c|c|c|}
\hline $\begin{array}{c}\text { sample } \\
\text { No. }\end{array}$ & $\begin{array}{c}0,2-0,6 \mathrm{~mm} \\
\text { number of } \\
\text { quartzgrains }\end{array}$ & $\begin{array}{l}\text { glacially crushed/ } \\
\text { freshly weathered }\end{array}$ & $\begin{array}{c}\text { dull(aeolian)/ } \\
\text { lustrous(fluvially } \\
\text { polished) }\end{array}$ & locality in Figure 3 \\
\hline 1 & 227 & $227=(100 \%)$ & $0=(0 \%)$ & No. 59 \\
\hline 2 & 210 & $210=(100 \%)$ & $0=(0 \%)$ & west of No. 59 \\
\hline 3 & 148 & $148=(100 \%)$ & $0=(0 \%)$ & No. 71 \\
\hline 4 & 45 & $45=(100 \%)$ & $0=(0 \%)$ & between No. 71 and 59 \\
\hline 5 & 76 & $76=(100 \%)$ & $0=(0 \%)$ & east of No. 71 \\
\hline 6 & 64 & $63=(98.44 \%)$ & $1=(1.54 \%)$ & south of No. 70 bottom \\
\hline 7 & 226 & $226=(100 \%)$ & $0=(0 \%)$ & south of No. 70 top \\
\hline 8 & 147 & $147=(100 \%)$ & $0=(0 \%)$ & between No. 71 and 57 \\
\hline 9 & 100 & $100=(100 \%)$ & $0=(0 \%)$ & between No. 59 and 56 \\
\hline 10 & 77 & $77=(100 \%)$ & $0=(0 \%)$ & north of No. 60 \\
\hline 11 & 51 & $51=(100 \%)$ & $0=(0 \%)$ & north of No. 60 \\
\hline 12 & 11 & $11=(100 \%)$ & $0=(0 \%)$ & east of No. 60 \\
\hline 13 & 62 & $62=(100 \%)$ & $0=(0 \%)$ & north of No. 51 \\
\hline 14 & - & - & - & \\
\hline 15 & 430 & $427=(99.3 \%)$ & $3=(0.7 \%)$ & south-west of No. 73 \\
\hline 16 & 70 & $69=(98.57 \%)$ & $1=(1.43 \%)$ & south-west of No. 77 \\
\hline 17 & 77 & $77=(100 \%)$ & $0=(0 \%)$ & between No. 83 and 84 \\
\hline 18 & 13 & $13=(100 \%)$ & $0=(0 \%)$ & south-east of No. 85 \\
\hline 19 & 155 & $155=(100 \%)$ & $0=(0 \%)$ & south-south-east of No. 93 \\
\hline 20 & 61 & $61=(100 \%)$ & $0=(0 \%)$ & west of No.54 \\
\hline 21 & 245 & $237=(96.74 \%)$ & $8=(3.26 \%)$ & south of No. 93 \\
\hline 22 & 148 & $148=(100 \%)$ & $0=(0 \%)$ & south-south-east of No. 93 \\
\hline 23 & 15 & $15=(100 \%)$ & $0=(0 \%)$ & north-west of No. 54 \\
\hline 24 & 58 & $56=(96.55 \%)$ & $2=(3.45 \%)$ & south-south-west of No. 93 \\
\hline 25 & 58 & $58=(100 \%)$ & $0=(0 \%)$ & Figure 2 No. 94 \\
\hline 26 & 126 & $126=(100 \%)$ & $0=(0 \%)$ & Figure 2 No. 95 \\
\hline 27 & 355 & $350=(98.6 \%)$ & $5=(1.4 \%)$ & Figure 2 No. 95 \\
\hline 28 & 97 & $95=(98 \%)$ & $2=(2 \%)$ & Figure 2 No. 95 \\
\hline 29 & 114 & $114=(100 \%)$ & $0=(0 \%)$ & Figure 2 No. 95 \\
\hline 30 & 609 & $605=(99.34 \%)$ & $4=(0.66 \%)$ & Figure 2 No. 95 \\
\hline $\begin{array}{l}\text { mean } \\
\text { value }\end{array}$ & 140,52 & $139,62=(99,49 \%)$ & $0,90=(0,51 \%)$ & 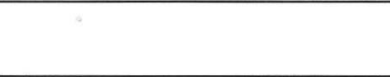 \\
\hline
\end{tabular}


a

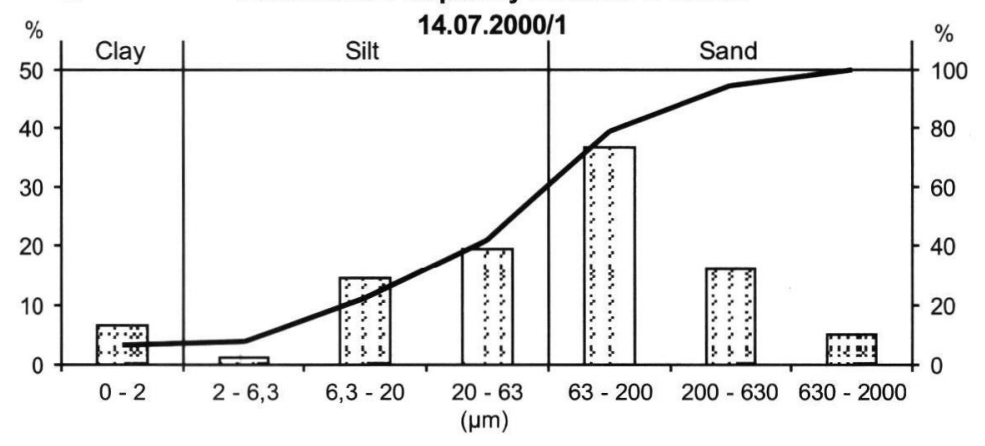

Ct: $\quad 1,53 \%$

Lime content: $1,19 \%$

\section{Cumulative Frequency Grain Size Curve}

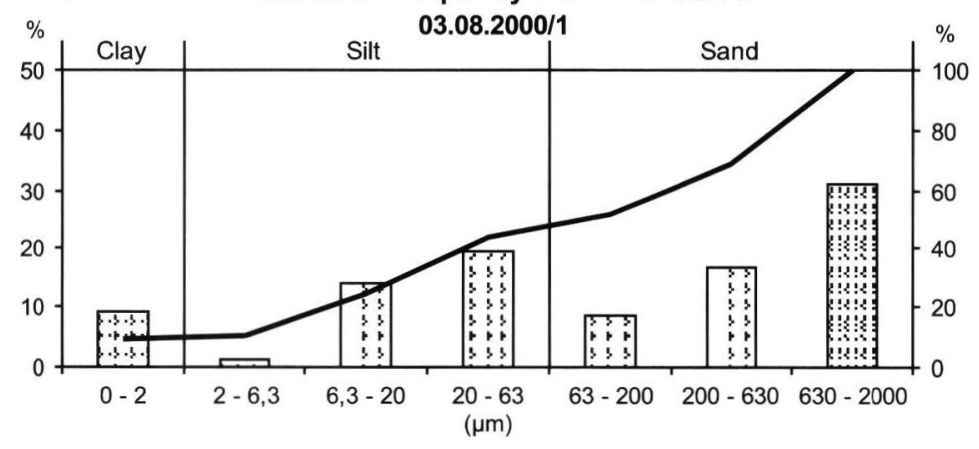

Ct: $\quad 1,01 \%$

Lime content: $0,69 \%$

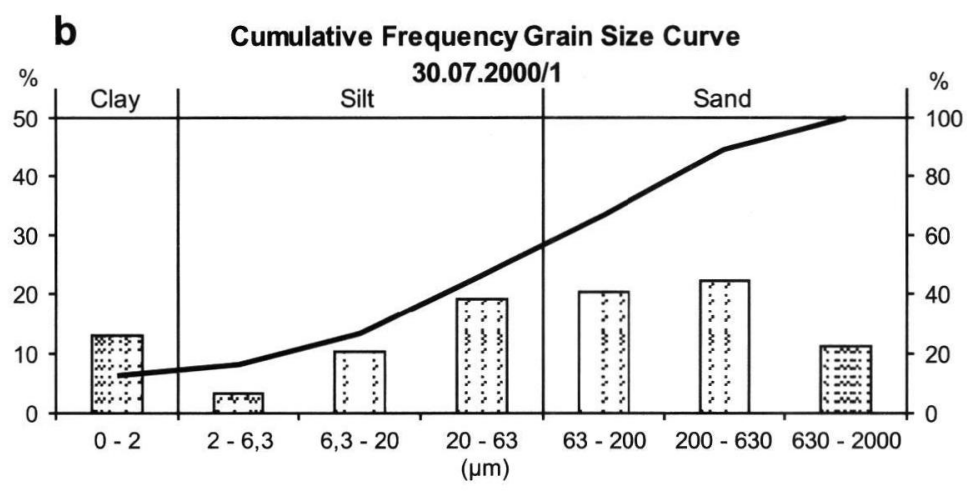

Ct: $\quad 0,6615 \% \quad \mathrm{~S}_{\mathrm{O}}=5,63$

Lime content: $0,33 \%$

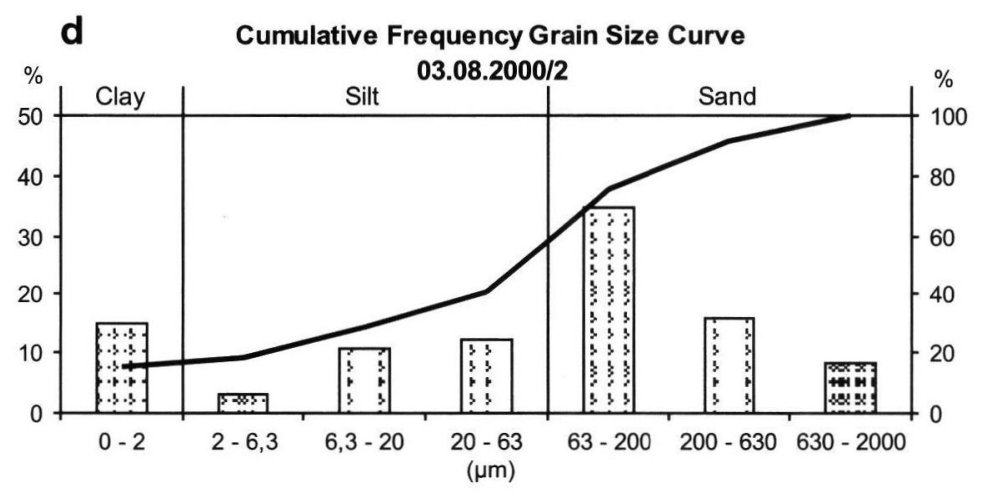

Ct: $\quad 1,52 \%$

Lime content: $0,51 \%$ 
Fig. 11: Grain size distribution of four till samples characteristic for the investigation area:

a: At $3550 \mathrm{~m}$ asl on the orographic left flank of the Chogolungma valley, lodgement till matrix (Fig. 9, left of black; Fig. 8a) taken $250 \mathrm{~m}$ above the current glacier from a depth of $0.3 \mathrm{~m}$. The superficial moraine layer has been sedimented during the Late Glacial stadium IV (= Sirkung-stadium; Tab. 1)). The primary maximum is relatively coarse-grained, i.e. it lies with $40 \%$ in the fine sand; the secondary maximum with $8 \%$ clay determines the bimodal course of the cumulative curve, which is typical of moraine matrix. The sorting coefficient calculated according to ENGELHARDT (1973:133) is So $=3.89$. So $=\sqrt{ } \mathrm{Q} 3 / \mathrm{Q} 1$ means: the ratio of the grain sizes of the first quarter Q1 of the grain size distribution curve is brought in relation to the third quarter Q3 in order to differentiate the fluvial and morainic accumulations. $\mathrm{Ct}$ is the content of carbon caused by the development of humus. Locality: Fig. 3, No. 59; 35 $53^{\prime} 10^{\prime \prime}$ N/75 13 '17'E; Fig. 4, on the right of Pro. 39. (see also Tab. 2, No. 1; Fig. 12)

b: Late Glacial lodgement till matrix of the Sirkung-stadium (IV) (Tab. 1) taken from a depth of $0.2 \mathrm{~m}$ from the orographic right flank of the Basna valley, c. $600 \mathrm{~m}$ above the talweg of this main valley. The skeleton portion of the moraine contains metres-sized erratic granite boulders, superimposed upon sedimentary bedrock. The bimodal cumulative curve runs very flat, i.e. a compact primary maximum reaches from the medium sand $(22 \%)$ via the fine sand $(21 \%)$ as far as the coarse silt $(20 \%)$; the clay peak reaches $13 \%$. Correspondingly, the sorting coefficient So $=5.63$ indicates a dispersed matrix (Fig. 12, Tab. 2, No. 12). Locality: Fig. 3, on the right of No. 60, above the settlement of Tisa Birri at 3547'20"N/ 75²2'55”E, 3230 $\mathrm{m}$ asl; Fig. 4, Pro. 42.

c: Late Glacial stadium IV (Tab. 1) end moraine matrix in the middle Satpare Lungma taken from $0.5 \mathrm{~m}$ below the surface. The skeleton portion of the decametres-thick accumulation contains granite boulders of some metres in size. Due to the thickness of the sediment the genesis of the matrix as a result of in situ weathering of the bedrock can be ruled out, i.e. horizontal transport has taken place. The arrangement of the columnar diagram is even trimodal. Similar to a bimodal course, this is a distinguishing feature in contrast to fluvial and limnic sediments. It depends on a prominent secondary maximum in the coarse silt (c. 20\%) between a primary maximum in the coarse sand (c. 30\%, deriving from the granite grit) and a tertiary in the clay (just 10\%); correspondingly important is the sorting coefficient So = 5.62 (Fig. 12; Tab. 2, No. 16). Locality: Fig. 3, half-left below No. 77; 3508’45”N/75³7’01”E; 3210 m asl.; Fig. 4, below Pro. 47.

d: Lodgement till matrix on the Deosai Plateau (Fig. 10, near the left margin in the background) taken from $0.4 \mathrm{~m}$ below the surface. The skeleton portion of the decametres-thick accumulation contains polymict boulders up to $0.6 \mathrm{~m}$ in length, so that a genesis of the matrix resulting from weathering of the bedrock in situ can be ruled out, i.e. horizontal transport has taken place. The clay- and silt-portions (c. $40 \%$ ) exclude fluvial transport. The arrangement of the columnar diagram is bimodal, indicated by a primary maximum in the fine sand (c. 33\%) and a prominent secondary one in the clay (c. 16\%). Considering a moraine, the sorting coefficient $\mathrm{So}=4.15$ lies in a middle position (Fig. 12; Tab. 2, No. 17). Locality: Fig. 3, between No. 83 and 84; Fig. 4, Pro. 49; 3504’20”N/75'29’30”E; $4000 \mathrm{~m}$ asl; Fig. 6c. Sampling: M. Kuhle. 
29 samples (Tab. 2, No.1-13 and 15-30: see mean values) and taken in the Karakoram from mainly high valley flank positions are glacially crushed (Fig. 12). Just this is already a very clear confirmation of the glaciogeomorphological findings introduced here.

Distributed over the research area, 25 glaciogeomorphological valley and glacier cross-sections (Fig. 4, Profiles 3-5, 37-58; Fig. 6, 8) indicate past trimlines from $6200 \mathrm{~m}$ asl (at the locality in Fig. 4, Profile 37) down to $3100 \mathrm{~m}$ asl (Fig. 4, Profile 58; Fig. 8). The first trimline is situated in the currently still glaciated regions of the highest summits in the Central Karakoram (Muztagh Karakoram (Fig. 2): K2 up to Ogre (Fig. 4) and the latter, lower trimline in the area of the Indus outlet glacier below the inflow of the Würmian Gilgit glacier (Fig. 4: Gilgit river). In the area of the present-day upper Baltoro glacier (Fig. 4) between K2, Broad Peak, Gasherbrum IV, Baltoro Kangri and Chogolisa, the ice has even reached $6300 \mathrm{~m}$ asl (maximum value: $6400 \mathrm{~m}$ asl). Thus, in the area of the current Biafo glacier (Fig. 4) the glacier surface of the last glacial period has also come to similar altitudes.

Correspondingly, in the areas of the present-day Chogolungma, Biafo and Baltoro glacier three dome-like ice culminations have existed in the glacier network of the last glacial period (Fig. 2 , frame of Fig. 3, 4). These very flat ice domes can be demonstrated by the reconstructed glacier cover, the height of the trimline and glacier thickness as well as by the entire Karakoram glacier network, at that time extending over c. $125,000 \mathrm{~km}^{2}$ (KuHLe 1988 b,1998), i.e. by a basal face which was much larger than that of our study area. The ice thickness depends on the extent of an ice dome and also on the mountain relief lying underneath, because this is decisive for the ground friction by ice outflow and the degree of ice accumulation. Accordingly, the extremely high mountain relief of the Karakoram with its enormous valley depths was the

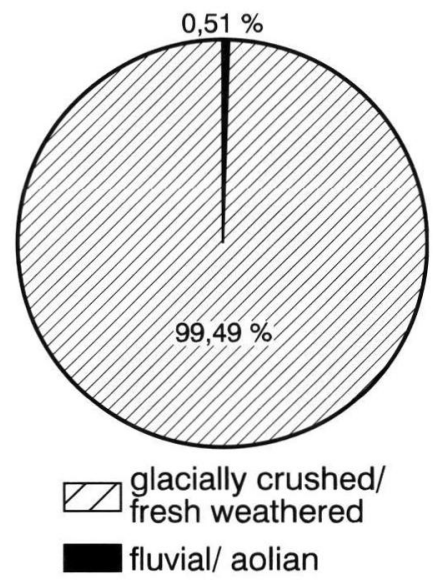

Fig. 12: The morphometric quartz grain analyses of 29 representative samples (cf. Tab. 2) yield a proportion of only $0.51 \%$ fluvially or aeolianly reworked grains. $99.49 \%$ of the quartz grains are glacially crushed, i.e. freshly weathered (cf. Fig. 11). Into the entire matrix which has been analysed, large erratic boulders are incorporated. This admixture of erratic material suggests that it is not bedrock of the underground weathered in situ, but solely glacially crushed material, which - on top of the bedrock might even have been secondarly weathered.

cause of the reconstructed ice thicknesses. The ice domes have communicated with each other via transfluence passes, i.e. they have formed an approximately continuous ice surface without today's breaks in slope. The levelling has taken place across the past transfluence passes, as indicated by smoothly-convex, rounded longitudinal profiles and trough-shaped crossprofiles with lodgement till, partly with erratics on the bottom. The ice cover of the Deosai Plateau (Fig. 2, 3, 4, 6c) has made up a fourth dome, from which outlet glaciers came down the valleys nearly symmetrically and in all directions (actiniformly) (Fig. 4). All these trimlines with their - visible on a large scale map - minor surface inclines, which are equidirectional, have met at the lowest point of their joint ice discharge exactly at the place where, $\mathrm{N}$ of Nanga 
Parbat, the Astor glacier has merged into the Indus glacier (Fig. 4, below Profile 58). Here, the talwegs join, too, so that the glaciers of the last glacial period flowed down-valley controlled by the relief.

In the middle Braldo valley (synonyms: Braldu, Biafo, Blaldo Lungpa), the ice thickness was about 2600-2900 m (Fig. 3, 4, Profile 3; Fig. $5,6 a, 7)$. In the Baltoro glacier valley it was C. 2400-2900 $\mathrm{m}$, in the Biafo glacier valley $2450-$ $2950 \mathrm{~m}$, in the Chogolungma glacier valley and the continuing Basna valley c. 1800-2900 m (Fig. 4, Profile 37-42; Fig. 8a).

In the valley mouths the Braldu glacier was still c. $2500 \mathrm{~m}$ - thick (Fig. 4, Profile 4 and 5; Fig. $6 \mathrm{~b}$ immediately down the Braldu valley) and the Basna glacier c. $2600 \mathrm{~m}$ (Fig. 4, Profile 43). All these glacier thicknesses of the main valleys of the Würmian Karakoram lay above, i.e. upvalley of the snow-line (cf. Fig. 4, cross-profile positions 3-44 with the climatic snow-line altitudes). They have still exceeded the maximum glacier thicknesses of the last glacial period of the Alpine glacier network - reaching c. 18002000 m (PENCK \& BRÜCKNER 1901-1909) - by $20-30 \%$, and may have had a glacioisostatic effect as far as a depression about $50-100 \mathrm{~m}$. In the very wide Shigar valley the ice thickness has been reduced from c. $2400 \mathrm{~m}$ (Fig. 4, Profile 5; Fig. 6b) via $2150 \mathrm{~m}$ (Profile 44) to c. $1300 \mathrm{~m}$ at the valley mouth. This corresponds approximately to the ice thickness in the connected Skardu Basin (Fig. 4, Profiles 45, 46), where it was c. $1500 \mathrm{~m}$ (Fig. 8c) and decreased to c. $1000 \mathrm{~m}$ towards the NW, i.e. the mouth of the basin. In the Indus gorge below the Skardu Basin the level of the glacier surface has only minimally dropped by 100 to $150 \mathrm{~m}$, but the ice thickness increased again up to $1700 \mathrm{~m}$ (Fig. 8b) as far as the Gilgit glacier (Fig. 4, Profiles 52-57). The reason for this is the deeply dissected and steep course of the gorge, showing numerous narrow bends. In this gorge the ice was nearly blocked, i.e., due to the resistance by friction, it flowed down very slowly. At the same time the gorge glacier has been dammed-up by the c. $1800 \mathrm{~m}$ thick Gilgit glacier (Fig. 8b) as far as its surface level at c. $3100 \mathrm{~m}$ asl. The Indus and the Gilgit glacier have both formed a parent glacier with a width up to $11 \mathrm{~km}$ (Fig. 4, Profile 58), which came in contact with the Astor glacier and the Nanga Parbat glacier network (Kunle 1997) and mediated to an ice margin at only just 800$850 \mathrm{~m}$ asl (KuHLe 1988b).

The trimline of the Deosai plateau glacier which was c. $24 \mathrm{~km}$ in diameter (Fig. 2, 3, 4), lay approximately between 4700 and $4900 \mathrm{~m}$ asl (Fig. 4, Profiles 48-50), so that ice thicknesses of c. $200 \mathrm{~m}$ above hill cupolas, and at most c. $900 \mathrm{~m}$ above the high valley bottoms, could be extrapolated as being probable (Fig. 6c). The Deosai outlet glaciers through the Satpare Lungma (Fig. 4, Profile 47) and Das Khilin Gah (Profile 51) have produced glacier connections to the Skardu Basin (Fig. 4, 8c), i.e. Astor valley (Fig. 4), and thus to the glacier network of the Karakoram S-slope, and at the same time to the Indus glacier network. In these terms, the Deosai glacier can be shown as being a part of this entirety.

The altitudes of the climatic glacier snowlines (ELA) (Fig. 4), in connection with the 25 cross-profiles of the valley glaciers, suggest that the communicating surface of the most productive glacier branches of this glacier network remained below the snow-line from the lower Shigar valley on as far as the Skardu Basin between Profile 44 and Profile 45 (cf. Fig. 4). Here, the ELA has run between c. 3700 and $3800 \mathrm{~m}$ asl during the last glacial period. From this one can draw the conclusion that in this area the surface moraine cover has started and, due to the growing ablation process down the Indus, may have increased rapidly. A condition for this is the feeding of the glaciers by avalanches from the steep faces of the highest mountains as e.g. K2 $(8616 \mathrm{~m})$, Broad Peak $(8047 \mathrm{~m})$, Gasherbrum IV (7980 m), Mash- 
erbrum $(7821 \mathrm{~m})$, Ogre (Baintha Brakk, 7285 m), Malubiting (7458 m), Haramosh (7409 m) etc., which has also taken place during the glacial periods. At that time these mountains still towered 1000-2000 $\mathrm{m}$ above the highest glacier surfaces. Even more debris has been produced by the participation of the numerous ground and lateral moraines, which in the narrow valley network were very massive and in the confluences have first met to form internal and then medial moraines. In the middle to lower Skardu Basin (Fig. 4, Profile 46) these surface moraines, which were made up of avalanche rock-debris and merged with medial moraines of the Central Karakoram (Muztagh: Fig. 2), might have completely covered the Indus parent glacier. The participation of the covering glaciation of the Deosai Plateau in this debris supply was only subordinated.

Despite this substantial, albedo-decreasing production of surface moraines, at least $80 \%$ of the surface of the glacier network were situated outside, i.e. at the same time above the surface moraine areas, so that they have reflected c. $75-90 \%$ of the global radiation on snow, firn and ice. The result of this was a cooling and autonomous amplification resulting in the buildup and preservation of the Karakoram glacier network (Kuhle 1988c).

The current snow-line altitudes of the glaciers (ELA) have been determined after the method of $v$. KLebelsberg (1948: 31) according to the condition of the glacier surface at places, where the fresh lateral moraines begin to thaw out. In the Karakoram the ELA-depressions could be appraised most immediately by arithmetical averaging of the lowest altitudes of current and past snow-line positions, following v. HöFER (1879). We know from experience that this is an integral method of approximation, which is only usable for paleoclimatic estimations (cf. Kunle 1988c; 1994). The lowest past glacier tongue of the Karakoram glacier network came down to c. $800 \mathrm{~m}$ asl (Indus parent glacier), i.e. on average c. $2600 \mathrm{~m}$ lower than the current valley glacier tongues. This evidences an ELAdepression of c. $1300 \mathrm{~m}$.

The empirically established ELA- (snowline-) depression of c. $1300 \mathrm{~m}$ suggests a drop in the average annual temperature of 7.8 to $9.1^{\circ} \mathrm{C}$ during the last glacial period. Whether the presentday precipitation, which decreases to $210-140$ $\mathrm{mm} / \mathrm{y}$ in the valleys but amounts to $1200-1500$ $\mathrm{mm} / \mathrm{y}$ at altitudes above $5000 \mathrm{~m}$ asl (see above), would have been sufficiently to create such an ice build-up at a higher relative humidity, or if the conditions were more hygric, cannot be estimated reliably. However, the reduced evaporation has led to the development of lakes in the currently arid Tarim Basin, Gobi Desert, Mongolia and in South-Siberia (WüNnEMANN et al. 1998). Perhaps the glacial ice build-up of the Karakoram system has also profited from their evaporation.

\section{Results concerning past glacier reconstruction in relation to other observations.}

The author's field investigations in 1997 and 2000 suggest that a continuous glacier network has existed over the entire research area (Fig. 2, frame: Figs. 3, 4; Figs. 3, 4). No glacier terminus of the last glacial period could be reconstructed. Only during the Late Glacial period this glacier network dispersed into dendritic valley glacier complexes of large dimensions. The High Glacial glacier network merged into the Indus glacier and had only one lowest glacier terminus, namely that of the Indus parent glacier (Fig. 2, hatched, on the left below the research area concerned, i.e. of frame Fig. 3 and 4). In the course of previous fieldwork done $115 \mathrm{~km}$ down-valley from the Nanga Parbat (113 km down from the junction of the Rakhiot valley) between the Sazin settlement and $20 \mathrm{~km}$ down the Indus (down from $35^{\circ} 32^{\prime} \mathrm{N} / 73^{\circ} 18^{\prime} \mathrm{E}$ ), the author has 
reconstructed this tongue end of the last glacial period of the Indus glacier at c. $850-800 \mathrm{~m}$ asl (Kuhle 1988a-c, 1989, 1991, 1997, 1998).

SHroder (1989: 144) approximately follows this reconstruction, suggesting a glacier terminus 25-100 km away from the Nanga Parbat, down the Indus.

Haserodt (1989) was, however, strongly opposed to it. He considered the lower section of the Indus valley to have been entirely free of a valley glacier and interpreted several of the moraines as deposits from local side valley glaciers. DAINelli (1922) has not visited this section of the Indus valley that is located down-valley of the Skardu Basin, but has assumed an 18 $\mathrm{km}$-long glaciation of the Indus valley for the Last Glacial Maximum (LGM), deriving from the Astor valley and the valleys of the Nanga Parbat massif exposed to WNW (ibid. Tav. CLXXVII). In contrast to the reconstruction of the author, which is based on field investigations, Dainelli's ice has only occupied the foot of the Nanga Parbat and has come to an end c. $95 \mathrm{~km}$ up-valley of the Indus glacier terminus suggested by the author. A further difference is that in DaINELli's map no Indus valley glacier is marked between this influx of the Astor valley glacier and the Skardu Basin, and hence over an Indus stretch of $150 \mathrm{~km}$. According to the assumption of DAINELLI an inflow of a valley glacier has not taken place from the Gilgit and lower Hunza valley either. The author, however, has evidenced a continuous Hunza-Gilgit ice stream for the last glacial period indicated by the occurrence of fresh glacier striae (KuHLE 1988b, 1989, 1991) (see Fig. 2 and 4). Within a few centuries or millennia these fresh striae, glacigenic rock polishes and abrasions as well as the rock roundings become reworked beyond recognition by weathering and denudation of walls and slopes. This process is accelerated by the steep relief of the Karakoram. Accordingly, it is impossible to consider the forms as being older than $60 \mathrm{ka}$ or even to classify them as belonging to the pre-last glacial period before c. $120 \mathrm{ka}$. Due to the very heavy denudation which has taken place in the steep relief of these mountains since deglaciation, the preservation of the forms under the moraine cover since the pre-last glacial period has to be ruled out, too. The Astor glacier, which DaInelli (1922) suggested as having reached the Indus, has been confirmed by the author's field investigations in 1987 (Kunle 1988b, 1997) (see Fig. 4). According to their fieldwork in1934 FinsterWALDER (1938: 174) and TROLL (1938a, b) contradict this opinion. They pointed out that the Astor glacier has come only somewhat farther than up to the Astor settlement and that the Astor valley, continuing in a downstream direction over 25-30 km, remained non-glaciated.

In this regionally larger context the reconstruction of the glaciation history of the Hindukush, which is situated northwest-adjacent to the investigation area, has to be mentioned (Fig. 1, near Tirich Mir; Fig. 2, No. 96). Haserodt (1989) has suggested that the Würmian Chitral glacier terminated c. $8 \mathrm{~km}$ up-valley of the Buni settlement, so that the Mastuj- or Chitral main valley was free of ice. KAMP (1999), in contrast, assumes that the past Chitral glacier has come at most $100 \mathrm{~km}$ further down-valley, up to the Drohse settlement at $1300 \mathrm{~m}$ asl. According to the author's reconstruction the Last Glacial period Chitral glacier has even flowed $15 \mathrm{~km}$ further down (Fig. 2, on the left above No. 97), i.e. as far as the valley chamber of Mirkhani at $1050-1100 \mathrm{~m}$ asl $\left(35^{\circ} 28^{\prime} 40^{\prime \prime} \mathrm{N} / 71^{\circ} 46^{\prime} 30^{\prime \prime} \mathrm{E}\right.$; Fig. 2, No. 97). This ice stream was not only thicker than $500 \mathrm{~m}$, as has been supposed by Kamp (1999: 189), but three-times thicker. Whilst KaMP (1999) does not assume a transfluence of the Tirich Mir glacier over the Zani pass, the author's findings of granitic erratics above the depression of the pass argue in favour of this transfluence (Fig. 2, No. 96). This gives evidence of a more important ice thickness.

As for a small part of the investigation area 
of this study, namely the Skardu Basin, glaciogeomorphological observations have been recorded in five papers. Besides Godwin \& Austen (1864), Dainelli (1922) and Norin (1925: Tavl. 5) also Owen (1988a, Fig. 2) and finally HaserodT (1989: 196/197) have misinterpreted the rock avalanche of Katzarah (Kachura) (Fig. 3, below No. 72) at the exit of the Skardu Basin as a moraine. It is not necessary to discuss once more the interpretation of these authors, who considered the valley-obstructing, coarse-blocky accumulation of Katzarah to be a Würmian end moraine. This has already been disproved by Hewitт (1999).

HASERODT 's (1989) interpretation, has already been discussed in detail (Kunle 1997). He describes that the lower Indus valley (see above) and also the Indus valley below the Skardu Basin were not occupied by an Würmian valley glacier, but that they have only been reached by the tongue ends of side valley glaciers.

Oestreich (1906), Dainelli (1922), Norin (1925) and Shroder, Owen \& Derbyshire (1993) have approached the Satpara Tso (lake) as being dammed-up by a terminal moraine. Dainelli (1922) and Norin (1925) classified this moraine as belonging to an ice margin position of an Würmian outlet glacier of the Deosai plateau. Additionally, the first author has suggested that it belonged to his "4th Advance". After Dainelli (I922) the deposits of the "3rd Advance" of the outlet glacier were left behind in the area of the Skardu settlement. Bürgisse et al. (1982), OwEN (1988b) and Cronin (1989) interpreted the massively disturbed gravel fan and lacrustine sediments as "glaciotectonic or disturbed till", so that the conclusion of Dainelli (1922) was confirmed. This contradicts HewitT (1999: 228-231) who not only queries the interpretation as "glaciotectonic", but also considers the accumulation damming-up the Satpara lake as being a "rock slide or rock avalanche" (Fig. 3, on the left above No. 77).
The author agrees nearly completely with Hewitts (1999: Fig. 7) opinion. "Nearly", because besides the correctly described rock avalanche deposits (Fig. 3, on the left above No. 77) and river terraces etc., accumulations of lodgement till do also exist in different altitudinal positions and states of preservation above those rock avalanche deposits on the orographic left side, 2 to $3 \mathrm{~km}$ up-valley of the Satpara Tso. With regard to the arrangement of the positions, the glacigenic abrasion forms and rock roundings are also connected with them (Fig. 3, half-left above No. 77). They provide evidence of a Würmian - ice level at about $3400 \mathrm{~m}$ asl, so that an ice thickness of c. $1000 \mathrm{~m}$ has been reconstructed. This suggests at the same time that the Satpara Tso rock avalanche(s) ("Satpara Lake-Skardu rock avalanche(s)") must have taken place in the Late Glacial or the Postglacial i.e., more exactly, that it (or they) occurred in this area after the deglaciation of the Satpare Lungma glacier during the Late Glacial stadium III (c. 14.250-13.500 YBP; cf. Tab. 1). Accordingly, the observation of OESTREICH (1906: 77), who has described here "considerably rounded gneiss boulders below a rock avalanche talus", can also be interpreted as being correct. That means, high-lying material of lodgement till is concerned, which has come down together with the rock avalanche(s) and survived relatively undamaged.

Thus, a tributary glacier, the Satpare Lungma glacier (Fig. 4, Profile 47), has joined the Indus glacier (the ice filling of the Skardu Basin, see above; Fig. 2 and 8c). It had still a surface height of about $3500 \mathrm{~m}$ at this junction. Correspondingly, there exists no "narrow gorge of the Satpua Valley" (Hewitt 1999: 228) at the exit of this valley, but rather a classic trough valley (Fig. 3 , on the left of No. 77), the upper slopes of which have been oversteepened by glacier flank erosion and, owing to this, have been prepared for the rock slide(s) or rock avalanche(s).

DAINELLI (1922) has not provided field observa- 
tions of the Indus valley from a few kilometres away from the Skardu Basin in a downstream direction, because he has not visited this area. However, for his Mindel- and Riß-glaciation (1st and 2nd glaciation) he has postulated an Indus glacier which he supposed to have filled the valley below the Skardu Basin. A certain inductively obtained anticipation of the author's results may be seen in Dainelli's observation that the Skardu Basin had been filled and polished out by the glacier ice during these two older (earlier than last glacial) glaciations. This assumption, however, is not based on a 1400 m-thick ice-filling of the basin, as has been reconstructed by the author (Fig. 4, Profiles 45, 46; Fig. 8c; Fig. 12; Tab. 2, No.15), but on a valley bottom, which during Dainelli's 1st Quaternary glaciation was still higher and - until the end of his 2nd glaciation (pre-last glacial period or Riss glaciation) - has been polished down to the level of the present-day rock bottom below the lake sediments and gravels. $\mathrm{He}$ describes and maps moraine-like deposits on the two "riegels" (bar mountains) Blukro (cf. Fig. 8c) and Karpochi (Fig. 2, 3 and 4: Skardu Basin) as well as on the basin flanks c. 500-1000 $\mathrm{m}$ above the valley bottom and classifies them as belonging to the 2 nd glaciation, without inferring from them the corresponding glacier thickness at that time. This may be explained by the fact that Dainelur considers the height of the trough bottom as having been much higher at the start of the 2nd glaciation than at its end, whilst he dates back the highest moraines to the start of the 2 nd glaciation. A further observation of Dainelli, which is important from the perspective of the findings introduced by the author, are the deposits mapped as "Morene della 2. espansione" at greater heights on both slopes of the Shigar valley. These are sediments confirmed by the author as lodgement tills (Fig. 3, from No. 50 via 47 up to 73; Fig. 4, Profiles 5 and 44; Fig. 6b; Fig. 12; Tab. 2, No. 13), but which he has classified as belonging to the last glacial period (Würmian)-glacier-filling (c. 60-18 ka). The chronological classification is based on the geomorphological, i.e. relative dating method and thus on an abundance of indicators (Fig. 3) as e.g. the preservation of moraines on steep slopes (e.g. Fig. 5, 7, 9) and the arrangement of their positions in relation to nearly unweathered glacier striae (e.g. Fig. 3, in the middle between No. 47 and 48) and related indicators of polishing as glacial flank polishing and abrasion (Fig. 3, and e.g. Fig. 5) - which naturally are rare in this morphodynamically active steep relief. In addition, $14 \mathrm{C}$ datings of peaty layers in valley - blocking positions and thermoluminescence datings of sediments on lateral and end moraines have been carried out (Kunle 1994:142/143, Table 2: 237: 264; 1997: 100, Table 2). ELA-calculations recording the snow-line depressions according to the last glacial period and Late Glacial glaciation, supported the chronological classification of the glacier positions (KUHLE 1988b: 588; 1994: 260, Table 3: 266/267; 1997: 123).

Summing up, the author recognizes the preserved glacier traces as indicators (Fig. 3) of the last glacial period (c. 60-18 ka), which have completely reshaped an older glacial landscape (developed during a previous stage of uplift of the Karakoram at a different sea-level). DAINELLI (I922) goes far back into the past that - due to the then inevitably very important influence of tectonic uplift, which is unknown for most parts - his findings allow neither a reconstruction of the trimlines or glacier thicknesses nor a paleoclimatic approach by calculations as to the snow-line and glacier surfaces. Compared with this, DAINELli's glacier reconstructions for his 3rd glaciation (Dainelli 1922) is realistic. Chronologically it belongs to the last glacial period, but, according to the author's observations in the field, it corresponds to the glacier extension during the High Glacial (Stadium 0 = Würmian in Tab.1) (in Kunle 1998: 82: Last Ice Age = Isotope Stage $2-4=$ c. $60-18 \mathrm{ka}=$ last 
glacial period) only in some areas - so e.g. on the Deosai Plateau (Fig. 2, 3, 6c, 11c, d; Fig. 12; Tab. 2, No. 16-18), whilst for the most part it applies to that during the Late Glacial period (stadium I-IV, cf. Tab. 1.).

\section{Conclusion: Postglacial rock avalanches as a confirmation of the past glaciation}

The reconstruction of rock avalanches in the Karakoram (HEwITT 1999), is an objection to the glaciation concept of DaINelli (1922) and the later literature (see above), which has misinterpreted the postglacial rock avalanches as end moraines of the last glacial and Late Glacial period. Due to their geomorphologically fresh status of preservation HewITT (1999) has classified the rock avalanches as being Holocene. This corresponds chronologically with the crumblings of glacigenically abraded trough flanks (see e.g. Fig. 5 and 7) which can be unambiguously diagnosed. HewitT (1999) introduces three examples of misinterpretation in our investigation area. The author completely agrees as to these isolated cases. At the same time, however, he does not recognize a contradiction of the glaciation history of the Karakoram, dicussed here (see 2. and 3.), but, in contrast, a confirmation.

According to the author's opinion, which contradicts Dainelli, especially in the Central Karakoram, no end moraines of the last glacial period (3rd espansione) are verifiable, because the glacier network had only one joint ice margin position in the lower Indus valley. In addition, the Late Glacial end moraines have not been preserved, but have been completely removed by the abundant and very erosion-effective meltwater in the forefield of the melting glacier network in the narrow valley receptacles. For this the forefield of the current and historic Biafo glacier (Fig. 7) provides a representative example. Instead of an end moraine, only a gravel floor (Fig. 7) has been preserved there. Owing to this, the author considers the concept of the search for end moraines in the Karakoram - pursued by many researchers - as methodologically wrong. Thus he has concentrated his work on the geomorphological analysis of the valley flanks (Fig. 3, 4, 6, 8, 11 and 12) and the search for lodgement till (Fig. 5, 7, 9, 10) and lateral moraines (Fig. 7), as well as on the observations of glacigenic flank abrasions and polishings (Fig. 5, 7, 9 and 10). It is mainly the reconstruction of the trimlines with the help of the highest erratics, remnants of lodgement till, glacier striae and polishings, abrasion roundings with upper lines of the polishing (Fig. 3), but also ends of wall gorges which enables a past glaciation in the high mountains to be estimated. The analysis of end moraines, however, is due mainly to the mountain forelands and lowlands. The glaciogeomorphological analysis of valley cross-profiles (Fig. 6 and 8) introduced here, which has led to the reconstruction of the Indus-Karakoram glacier network (Fig. 2 and 4 ), confirms the destabilisation of the valley flanks by the realization of glacigenically oversteepened trough valley cross-profiles (Fig. 5; Fig. 6a, SSE valley flank; Fig. 6d, NNW valley flank). Accordingly, rock avalanches as described by Hеwitт (1999) confirm the 1000 to $2900 \mathrm{~m}$ thick glacier network as the condition for those prolific Postglacial crumblings (Fig. 3 and e.g. Fig. 5 and 7). As for the NW-Karakoram Kuhle, Meiners \& Iturrizaga (1998) came to a corresponding conclusion.

Andersen (2000: 63) introduces several examples of Late- to Postglacial rock avalanches from Norway, as e.g. the Gloppedalsura rock avalanche in the glacigenic Gjesdal. These can also be explained by reshaping of the Ice Age glacial landscape. 


\section{References}

Andersen, B. G. (2000): Ice Age Norway: landscapes formed by Ice Age Glaciers. - 1216; Oslo (Univ.-Forl).

Bürgisser, H.M., Gansser, A. \& Pika, J. (1982): Late glacial lake sediments of the Indus valley area, northwestern Himalaya.Ecologae geologica Helvetica, 75 (1): 51-63; Basel.

Cronin, V.S. (1989): Structural setting of the Skardu intermontane basin, Karakoram Himalaya, Pakistan. - Geological Society of America Special Paper, 232: 213-216; Washington.

Dainelli, G. (1922): Studi sul Glaciale. - In: Zanichelli, N. (Ed.): Risultati Geologici e Geografici, Relazioni scientifiche della Spedizione Italiana De Fillipi nell' Himalaya, Caracorum e Turchestan Cinese (1913-1914). - Vol. III, Ser. II.: 1-655, Fig. 73, 177 Taf.; Tavole, Bologna .

Ding, Y. (1987): The study of the ThermoHydrological Environment of Glacial Development in the Karakoram Northside. - Lanzhou, VR-China (unpublished manuscript).

Engelhardt, W. v. (1973): Die Bildung von Sedimenten und Sedimentgesteinen.- In: Füchtbauer, H. \& Müller, G. (Hrsg.): Sediment-Petrologie, III: 1-378; Stuttgart (Schweizerbart'sche Verlagsbuchhandlung).

Finsterwalder, R. (1938): Die geodätischen, gletscherkundlichen und geographischen Ergebnisse der Deutschen Himalaya Expedition 1934 zum Nanga Parbat.Deutsche Forschung, Neue Folge, Schriften d. Deutschen Forschungsgemeinschaft; 2: 1201, 41 Abb., 1 Farbtafel, 8 Beilagen; Berlin (Karl Siegismund Verlag).

Godwin Austen, H.H. (1864): On the Glacies of the Muztagh Range.- Proceedings of the Royal Geographical Society, 34: 19-56.

Haserodt, K. (1989): Zur pleistozänen und postglazialen Vergletscherung zwischen Hindukusch, Karakorum und Westhimalaya.- Beiträge und Materialien zur Regionalen Geographie, 2; Hochgebirgsräume Nordpakistans im Hindukush, Karakorum und Westhimalaya: 181-233, 14 Abb.; Berlin.

HewitT, K. (1999): Quaternary Moraines vs Catastrophic Rock avalanches in the Karakoram Himalaya, Northern Pakistan. Quaternary Research, 51: 220-237, 11 Fig., 4 Tab.; Seattle.

Höfer, H. v. (1879): Gletscher- und Eiszeitstudien. - Schriften d. Akad. d. Wiss. Wien, Math.-naturw. Kl. 74, 79; Wien.

KaMP, U. (1999): Jungquartäre Geomorphologie und Vergletscherung im östlichen Hindukusch, Chitral, Nordpakistan.- Berliner Geographische Studien, 50: 1-254; Berlin.

Klebelsberg, R. v. (1948): Handbuch der Gletscherkunde und Glazialgeologie. - Bd.1 u. 2 : 1-403 + 404-1028, 93 Abb.; Wien (Springer).

KöHN, M. (1928): Bemerkungen zur mechanischen Bodenanalyse III. Ein neuer Pipettapparat. - Z. Pflanzenern. Düng. Bodenkunde., A 11, 50-54.

Kuhle, M. (1988a): Zur Geomorphologie der nivalen und subnivalen Höhenstufe in der Karakorum-N-Abdachung zwischen Shaksgam-Tal und K2 Nordsporn: Die quartäre Vergletscherung und ihre geoökologische Konsequenz. - Tagungsbericht und wissenschaftliche Abhandlung des 46. Deutschen Geographentag 1987 München 12.-16. Okt. 1987: 413-419, 8 Fig.; Stuttgart (Steiner).

Kunle, M. (1988b): The Pleistocene Glaciation of Tibet and the Onset of Ice Ages - An Autocycle Hypothesis.- GeoJournal, 17: 581-595, 13 Fig.; Dordrecht.

Kuhle, M. (1988c): Die eiszeitliche Vergletscherung W-Tibets zwischen Karakorum und Tarim-Becken und ihr Einfluß auf 
die globale Energiebilanz. - Geographische Zeitschrift, 76 (3): 135-148; Stuttgart.

Kunle, M. (1989): Die Inlandvereisung Tibets als Basis einer in der Globalstrahlungsgeometrie fußenden, reliefspezifischen Eiszeittheorie. - Petermanns Geographische Mitteilungen, 133 (4): 265-285, 20 Abb.; Gotha.

Kunle, M. (1991): Die Vergletscherung Tibets und ihre Bedeutung für die Geschichte des nordhemisphärischen Inlandeises. Sitzungsber. d. Akademie d. Wissensch. u. d. Literatur Mainz, Paläoklimaforschung, 1: 293-306., 8 Abb.; Stuttgart.

Kuhle, M. (1994): Present and Pleistocene Glaciation on the North-Western Margin of Tibet between the Karakorum Main Ridge and the Tarim Basin Supporting the Evidence of a Pleistocene Inland Glaciation in Tibet. - GeoJournal, 33 (2/3): 133-272, 138 Fig., 3 Tab.; Dordrecht.

Kunle, M. (1997): New Findings concerning the Ice Age (Last Glacial Maximum) Glacier Cover of the East-Pamir, of the Nanga Parbat up to the Central Himalaya and of Tibet, as well as the Age of the Tibetan Inland Ice. - GeoJournal, 42 (2-3): 87-257, 50 Fig., 4 Tab., 151 Photos; Dordrecht.

KuHLE, M. (1998): Reconstruction of the 2.4 Million sqkm Late Pleistocene Ice Sheet on the Tibetan Plateau and its Impact on the Global Climate. - Quaternary International, 45/46: 71-108, 28 Fig., 2 Tab.; Oxford.

Kuhle, M., Meiners, S. \& Iturrizaga, L. (1998): Glacier-induced Hazards as a Consequence of glacigenic Mountain Landscapes, in particular glacier- and moraine-dammed Lake outbursts and Holocene Debris production.- In: Kalvoda, J. \& Rosenfeld, C.L. (Eds.):Gemorphological Hazards in High Mauntain Areas. The GeoJournal Library: 63-96, 6 Fig., 10 Photos; Netherlands (Kluwer Academic Publisher).

Mahaney, W. C. (1995): Glacial crushing, weathering and diagenetic histories of quartz grains inferred from scanning electron microscopy. - In: Menzies, J. (Eds.): Modern Glacial Envivonments - Processes, Dynamies and Sediments, Vol. I: 487-506; London (Pergamon).

Miehe, G., Winiger, M., Böhner, J.\& Zhang, Y. (2000): Climatic Diagram Map of High Asia 1: 4000 000. Cartography: Enderle, C., printed by LVA NordrheinWestfalen, Marburg.

Norin, E. (1925): Preliminary notes on the late Quaternary glaciation of the Northwest Himalaya. - Geografiska Annaler, 7: 166194

Oestreich, K. (1906): Die Täler des nordwestlichen Himalaya. Beobachtungen und Studien.- Petermanns Geographische Abhandlungen, Ergänzungsheft, 155: 1-106, 36 Photos, 39 Fig., 1 Karte; Gotha.

Owen, L. (1988a): Terraces, Uplift and Climate, the Karakoram Mountains, Northern Pakistan. - Ph.D. thesis, Department of Geography, University of Leicester, UK (unpublished).

OWEN, L. (1988b): Wet-sediment deformation of Quaternary and recent sediments in the Skardu Basin, Karakoram mountains, Pakistan.- In: Сroot, D.G. (Eds.): Glaciotectonics. Forms and Processes; Rotterdam (Balkema).

Penck, A., Brückner, E. (1901-1909): Die Alpen im Eiszeitalter. - 3 Bd.; 1199 S. Leipzig (Tauchnitz).

SHroder, J.F. (1989): Hazards of the Himalayas. - American Scientist, 7: 564-573.

Shroder, J.F., Owen, L. \& Derbyshire, E. (1993): Quaternary glaciation of the Karakoram and Nanga Parbat Himalaya. - In: Shroder, J.F., Jr. (Ed.): Himalaya to the sea: Geology, Geomorphology and the Quaternary: 132-158; New York (Routledge).

Troll, C. (1938a): Der Nanga Parbat als geographische Erscheinung. Ein 
Bildbericht. - Zeitschrift für Erdkunde, 6 XIE, Z. (1987): The Characteristics of the (1/7): 304-313, 14 Abb.; Frankfurt/Main. Troll, C. (1938b): Der Nanga Parbat als Ziel deutscher Forschung. - Zeitschrift der Gesellschaft für Erdkunde Berlin, 73: 1-26, 9 Abb., 1 Fig., 3 Tab.; Berlin.

Wünnemann, B., Pachur, H.-J., Li Jijun \& Zhang, H. (1998): Chronologie der pleistozänen und holozänen Seespiegelschwankungen des Gaxun Nur / Sogo Nur und Baijian $\mathrm{Hu}$, Innere Mongolei, Nordwestchina. - Petermanns Geographische Abhandlungen, 142: 191-206, 8 Fig.; Gotha. Present Glaciers on the North-slope of K2. - Lanzhou, VR-China (unpublished manuscript).

Map:

Operational Navigation Chart (1974): G-7, Scale 1: 1,000,000, Edition 5; Defense Mapping Agency Aerospace Center, St. Louis Air Force Station, Missouri 63118, compiled July 1974 